RHO-BWI-LD-22

Informal Report

\title{
Site Identification Presentation Basalt Waste Isolation Project
}

Staff

November 1979

MASTER

Prepared for the United States

Department of Energy

Under Contract DE-AC06-77RL01030

Rockwell International

Rockwell Hanford Operations

Energy Systems Group

Richland, WA 99352 


\section{DISCLAIMER}

This report was prepared as an account of work sponsored by an agency of the United States Government. Neither the United States Government nor any agency Thereof, nor any of their employees, makes any warranty, express or implied, or assumes any legal liability or responsibility for the accuracy, completeness, or usefulness of any information, apparatus, product, or process disclosed, or represents that its use would not infringe privately owned rights. Reference herein to any specific commercial product, process, or service by trade name, trademark, manufacturer, or otherwise does not necessarily constitute or imply its endorsement, recommendation, or favoring by the United States Government or any agency thereof. The views and opinions of authors expressed herein do not necessarily state or reflect those of the United States Government or any agency thereof. 


\section{DISCLAIMER}

Portions of this document may be illegible in electronic image products. Images are produced from the best available original document. 


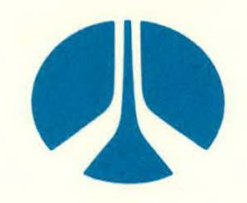

\title{
Rockwell International
}

Rockwell Hanford Operations

Energy Systems Group

Richland, WA 99352

\author{
PREPARED FOR THE UNITED STATES DEPARTMENT OF ENERGY \\ UNDER CONTRACT DE-AC06-77RL01030
}

\section{PRELIMINARY REPORT}

This Report contains information of a preliminary nature. It is subject to revision or correction and therefore does not represent a final Report. It was prepared primarily for internal use within The Rockwell Hanford Operations. Any expressed views and opinions are those of the Author and not necessarily of the Company.

NOTICE

This Report was prepared as an account of work sponsored by the United States Government. Neither the United States nor the United States Department of Energy, nor any of their Employees, nor any of their Contractors, Subcontractors, or their Employees, makes any warranty, express or implied, or assumes any legal liabilıty or responsibılity for the accuracy, completeness, or usefulness of any information, apparatus, product or process disclosed, or represents that its use would not infringe privately owned rights. 
RHO-BWI-LD-22

Informal Report

SITE IDENTIFICATION PRESENTATION

Basalt Waste Isolation Project

Staff

November 1979

Rockwe 11 International

Rockwe11 Hanford Operations

Energy Systems Group

Richland, Washington 99352 


\section{SUMMARY REPORT - BASALT WASTE ISOLATION PROJECT}

\section{SITE IDENT IFICATION}

The Basalt Waste Isolation Project of Rockwell Hanford Operations, under contract with the U.S. Department of Energy, is aimed at examining the feasibility of disposing of nuclear waste in a deep repository in basalt beneath the Hanford Site.

One of the major tasks of the Basalt Waste Isolation Project consists of identifying any sites within Hanford which are suitable locations for a nuclear waste repository. This si.te identification task began in 1978 with prellminary geologic and hydrologic reconnaissance studies and will be completed in September 1981 with the submittal of a Site Characterization Report describing the site identified for locating such a repository. The Site Characterization Report will also contain a plan detailing the work to be done to assess fully whether or not the site identified satisfies the U.S. Nuclear Regulatory Commission criteria for nuclear waste repositories.

The site identification process to date has involved:

1. The development of guidelines and decision theory;

2. The assemblage and cataloging of existing data;

3. The screening of the data using a structured process;

4. The identification of candidate sites; and,

5. The selection of preferred sites for preliminary characterization.

All of these steps have now been completed. A final step in the site identification process, which is now under way, involves reducing the several preferred sites to only one.

Guidelines for screening were developed based on a careful analysis of existing and proposed regulations.(1-6) The resulting guidelines are presented at the end of this report. The decision theory used was drawn from acceptable methodology used in nuclear reactor siting analysis.

The data required for identification were based on the U.S. Nuclear Regulatory Commission's proposed general statement of work (1) that the proposed repository site would comply with the National Environmental Policy Act. Thus, it was concluded that the site must meet the following objectives:

1. Assure public health and safety;

2. Mitigate adverse environmental and socioeconomic impacts; and,

3. Minimize cost necessary to attain the requisite levels of safety, as well as cost of mitigation. 
Data used for site identification included all the existing geologic, hydrologic, and engineering data available to date within the Pasco.

Basin. (Figure 1). The Pasco Basin was selected as the study area since it is the structural entity within which the Hanford Site is located: The basin corresponds to one of the thickest accumulations of Columbia Plateau basalts.

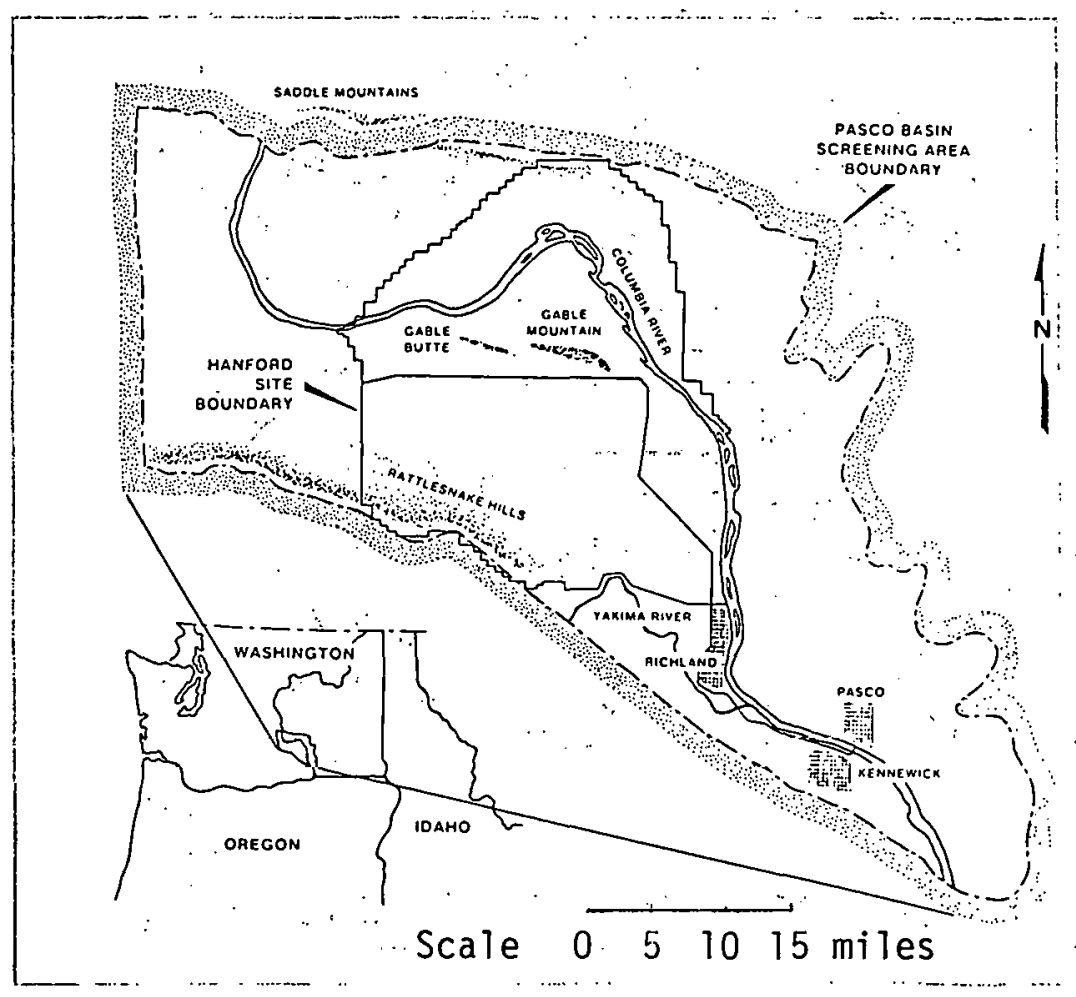

FIGURE 1. The Study Area.

The geology and hydrology of the Pasco Basin have been intensely studied for the past 10 years with more concentrated study during the last 2 years. A principal result of these studies was the discovery that, at depths of between 2,500 to 4,500 feet beneath the Hanford Site, there are a few laterally extensive Columbia River Basalt lava flows which are internally dense and thick (nearly 200 feet). The thick, dense interiors of these lava flows are the candidate host rock units for a. repository. Such candidate host rock units can be identified with a high degree of certainty in surface outcrops and in core holes, and their locations can be projected between boreholes with confidence? 
The screening process used the guidelines to reduce the study area to 9 candidate sites of approximately 10 square miles in size (Figure 2). Each of these sites satisfies the guidelines imposed in the screening process.

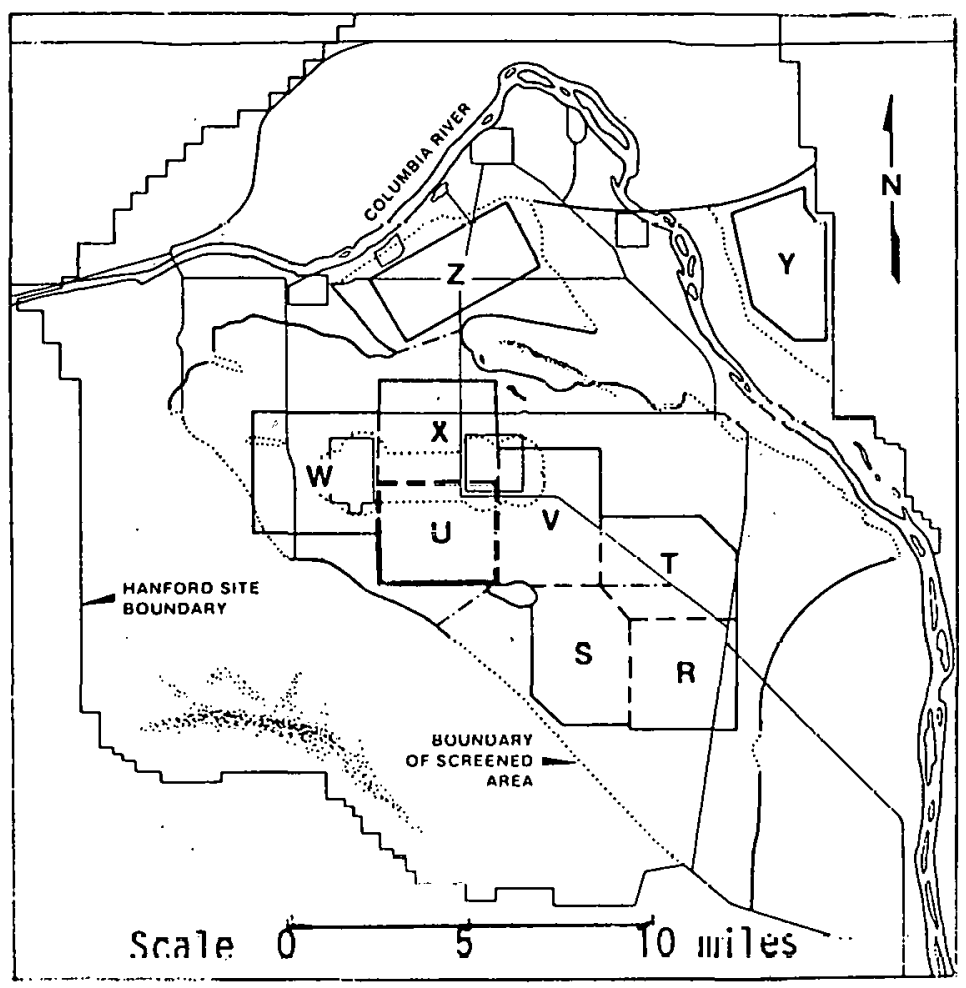

FIGURE 2. Candidate Sites Obtained through the Screening Process.

Trade-off studies using the techniques of dominance analysis $(7,8)$ are being conducted to preferentially order the sites identified. By September 1981, one of these nine sites will be finally selected as the preferred site for further characterization studies. The recommended site will be described in the Site Characterization Report.

The site evaluation activities to be initiated in September 1981 will conform to the criteria defined by the U.S. Nuclear Regulatory Commission as provided in the final version of Title 10, Code of Federal Regulations, Part 60, "Licensing Requirements for Nuclear Repositories." The current siting studies for a repository in basalt are based upon the siting requirements for nuclear power plants and the most recent drafts of the above-named regulation. 
The objective of site evaluation will be to accurately define the geologic and environmental conditions to assure public safety and to obtain approval for construction and, subsequently; an operating license for a nuclear waste repository. This objective will be attained by means of additional research investigations.

Results of site evaluation activities will be reported in the Construction License application and in the Environmental Report to be completed by September 1983.

\section{REFERENCES}

1. Proposed Statement of General Policy: Licensing Procedures for Geologic Repositories for High-Leve] Radioactive Wastes, Federal Register 78-53869-78-53872, U. S. Nuclear Regulatory Commission, Washington, D.C., 1978.

2. 10 CFR Part 60, Draft, Licensing Requirements for Nuclear Repositories.

3. Geologic Criteria for Repositories for High-Level Radioactive Wastes, National Research Council pamphlet, National Academy of Sciences, Washington, D.C., 1978.

4. Site Selection Factors for Repositories of Solid High-Level and AlphaBearing Wastes in Geological Formations, Technical Reports Series Number 177, International Atomic Energy Agency, Vienna, Austria, 1978.

5. Draft, NWTS Criteria for the Geologic Disposal of Radioactive Waste, ONWI 33-2 (2), Office of Nuclear Waste Isolation, Battelle Memorial Institute, Columbus, Ohio, 1979.

6. Environmental Protection Guidance on Radioactive Waste Disposal for Federal Agencies, U.S. Environmental Protection Agency, Washington, D.C., 1970 .

7. Keeney, R. L. and Nair, K., Evaluating Potential Nuclear Power Plant Sites in the Pacific Northwest using Decision Analys is: Energy Policy, V. 5, No. 1, Woodward-Clyde Consultants, San Francisco, California, 1977.

8. Raiffa, H., Decision Analysis, Introduction Lectures on Choices under Uncertainty, Addison-llesley Publishing Company, Reading, Massachusetts, 1968. 
INTRODUCTION 


\section{IDENTIFICATION OF CANDIDATE SITES STUDY GOAL}

IDENTIFY POTENTIALLY SUITABLE SITES FOR A NUCLEAR WASTE REPOSITORY IN BASALT 


\section{STUDY AREA}

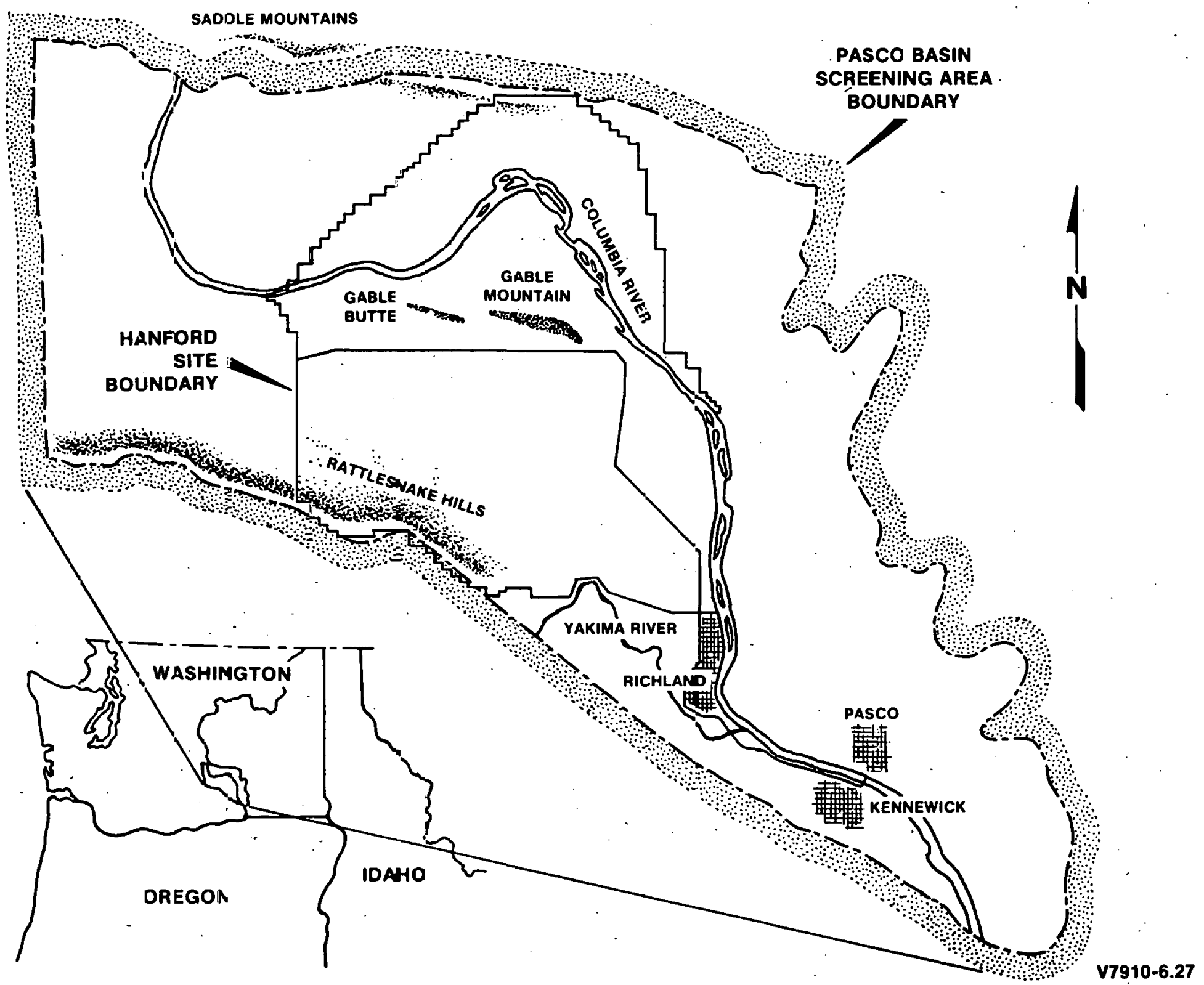




\section{SITING PROCESS}

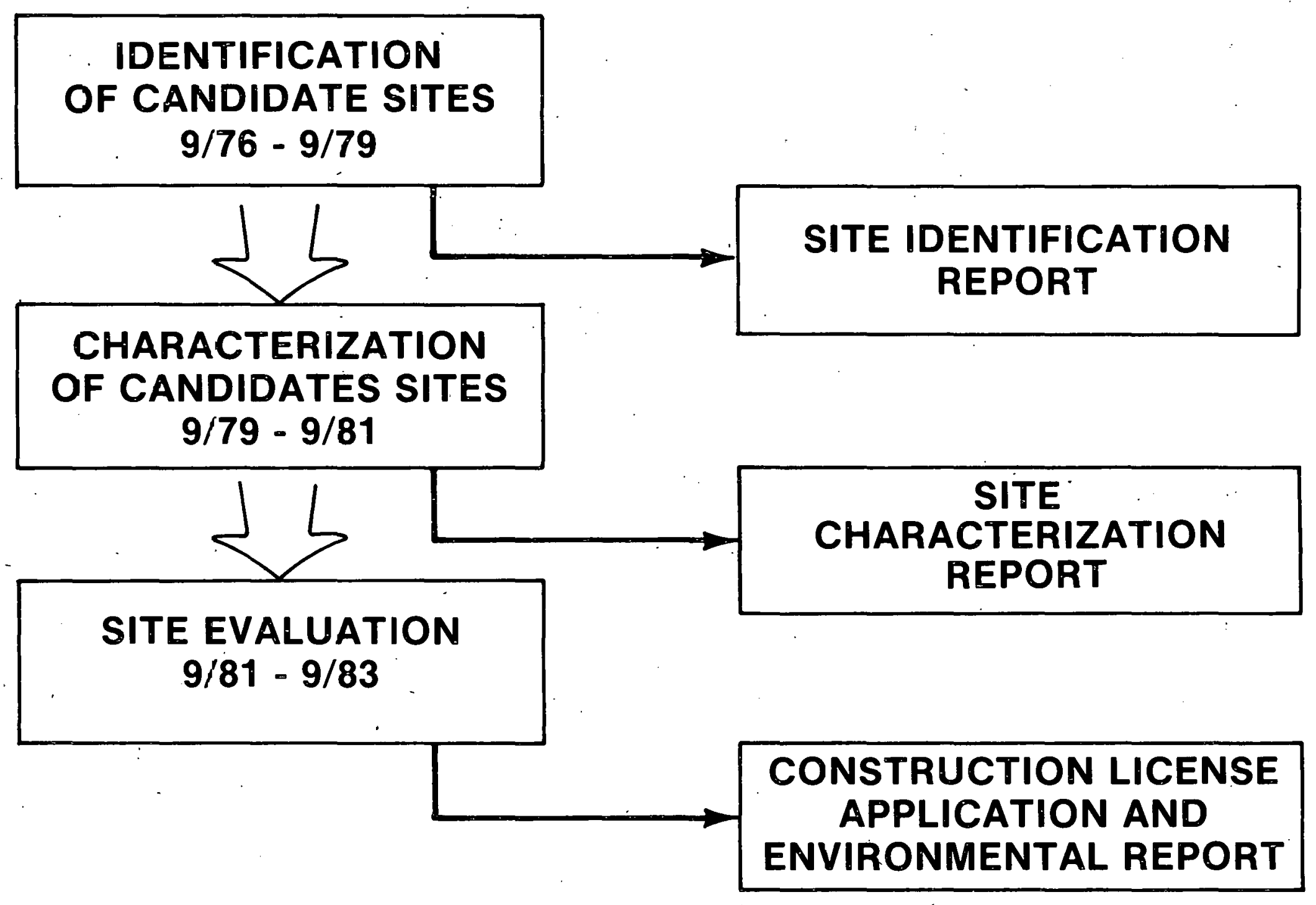




\section{AGENDA}

- SUMMARY OF GEOLOGY OF THE PASCO BASIN

- SUMMARY OF HYDROLOGY OF THE PASCO BASIN

- SITE IDENTIFICATION METHODOLOGY

- SCREENING AND IDENTIFICATION

- GEOLOGIC SUPPORT INFORMATION

- SUMmARY 


\section{SITE IDENTIFICATION METHODOLOGY}




\section{SITE IDENTIFICATION APPROACH}

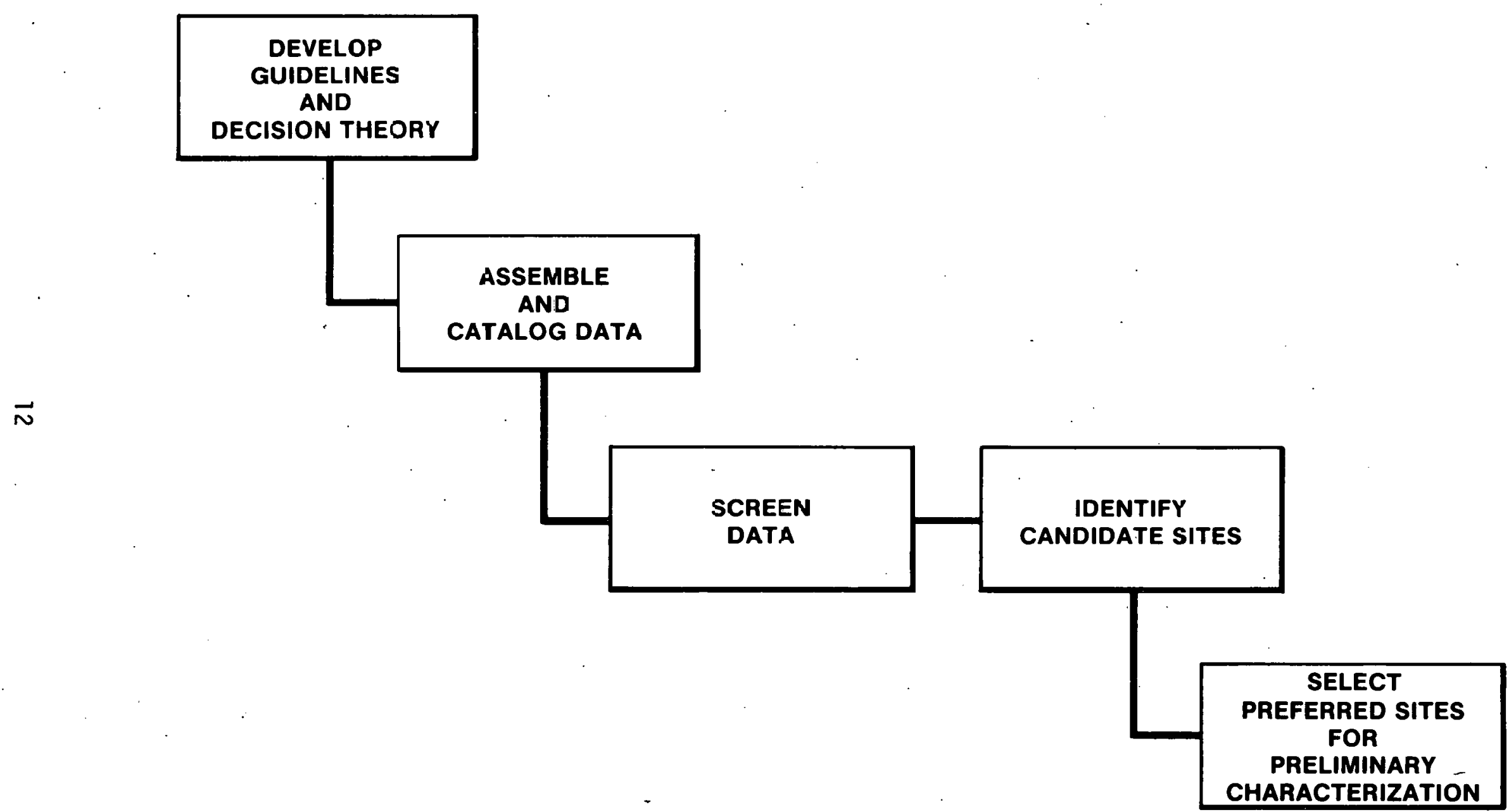




\section{SAMPLE BASELINE REQUIREMENTS USED IN GUIDELINE DEVELOPMENT}

- TOTAL SURFACE AREA REQUIRED

- DEPTH TO REPOSITORY LEVEL

- TOTAL SUBSURFACE AREA REQUIRED

- NOMinal CONFiguration

- DESIGN BASIS EARTHQUAKE

- DIP OF BASALT FLOWS

- THICKNESS OF BASALT FLOWS

- TIME FRAME OF OPERATIONAL AND ISOLATION PERIODS

- EXCLUSION OF RADIOLOGICALLY CONTAMINATED AREAS

- LICENSING AUTHORITY 


\section{SAMPLE BASELINE SOURCES FOR GUIDELINE DEVELOPMENT}

- NUCLEAR REGULATORY COMMISSION

10 CFR 60 RADIOACTIVE WASTE DISPOSAL

10 CFR 50 REPROCESSING PLANTS

10 CFR 100 POWER PLANT SITING

- ENVIRONMENTAL PROTECTION AGENCY

CLEAN AIR ACT

NATIONAL POLLUTION DISCHARGE ELIMINATION SYSTEM

- NATIONAL ACADEMY Of SCIENCES

- INTERNATIONAL ATOMIC ENERGY AGENCY

- OFFICE OF NUCLEAR WASTE ISOLATION

- ROCKWELL TECHNICAL REQUIREMENTS

- INDUSTRIAL AND SCIENTIFIC EXPERIENCE 


\section{RELATIONSHIPS OF TERMS USED IN SITE IDENTIFICATION}

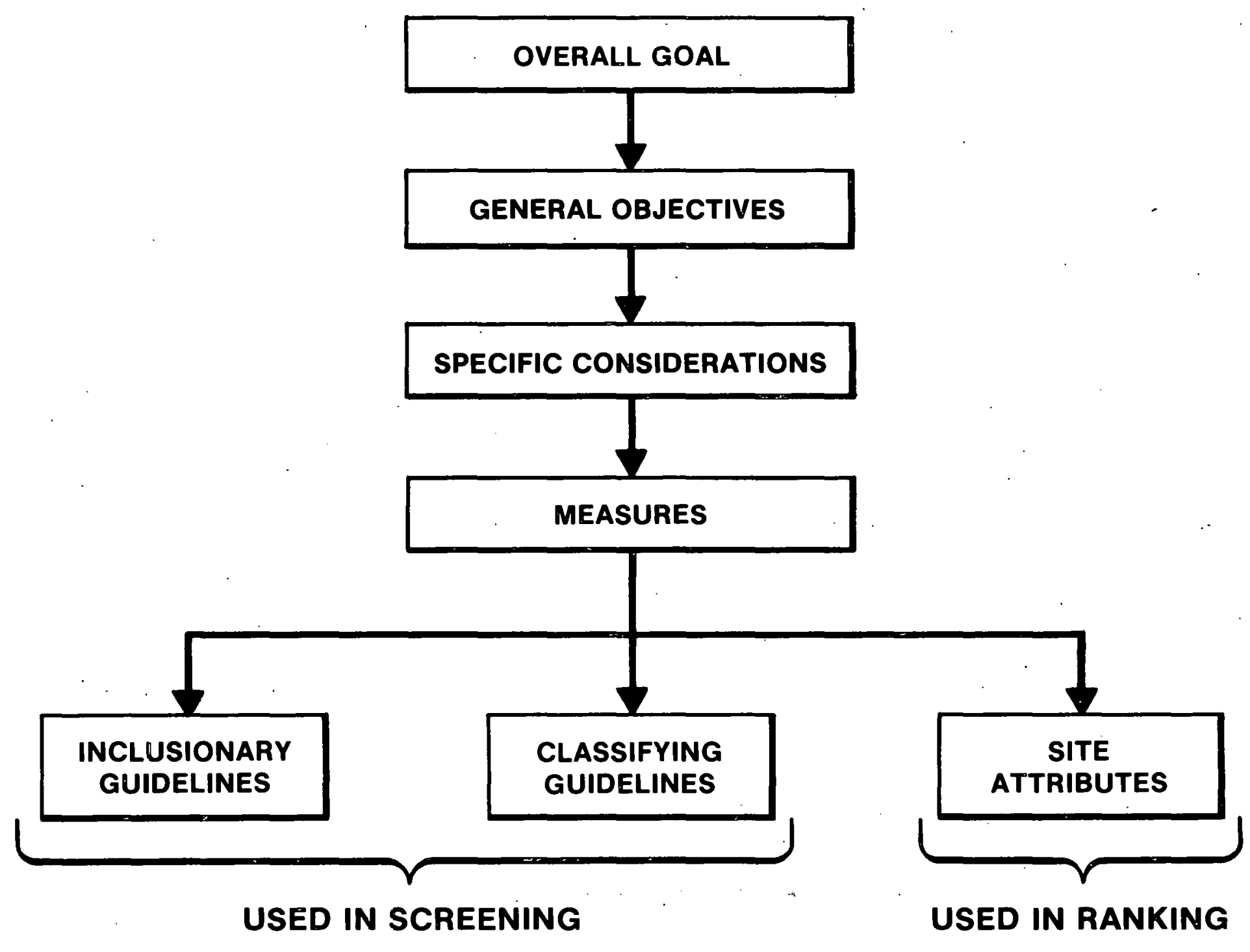




\section{OVERALL GOAL:}

IDENTIFY CANDIDATE SITES WHICH HAVE A HIGH LIKELIHOOD OF CONTAINING SUITABLE SITES

FOR LOCATING A RADIOACTIVE WASTE REPOSITORY 


\section{GENERAL OBJECTIVES}

- ASSURE PUBLIC HEALTH AND SAFETY

- MITIGATE ADVERSE ENVIRONMENTAL AND SOCIO-ECONOMIC IMPACTS

- MINIMIZE SYSTEM COSTS 


\section{SPECIFIC CONSIDERATIONS}

TECHNICAL CONCERNS THAT DESCRIBE THE SUBJECT MATTER THAT MUST BE ADDRESSED TO ORIENT THE SITING STUDY TOWARD ACHIEVEMENT OF THE GENERAL OBJECTIVES 


\section{MEASURES}

PROVIDE A MEANS OF ASSESSING THE DEGREE TO WHICH A REPOSITORY CAN ACHIEVE AN OBJECTIVE IN TERMS OF SPECIFIC CONSIDERATIONS 


\section{INCLUSIONARY GUIDELINE}

REPRESENTS AN ACCEPTABLE LEVEL OF ACHIEVEMENT FOR AN OBJECTIVE IN TERMS OF THE CONSIDERATION UNDER STUDY, BASED DN REGULATORY OR STATUTE REQUIREMENTS, TECHNOLOGICAL LIMITATIONS, OR GROSS ECONOMICS 


\section{CLASSIFYING GUIDELINE}

IDENTIFIES GROUPS OF AREAS WITH SIMILAR

CHARACTERISTICS AND CLASSIFIES EACH AREA WITH

RESPECT TO THE DIFFICULTY IN ACHIEVING ACCEPTABLE

LEVELS OF SAFETY OR PERFORMANCE WITHOUT

REQUIRING A FINITE LEVEL OF ACHIEVEMENT 


\section{SITE ATTRIBUTE}

QUANTIFIABLE MEASURES WHICH DESCRIBE

A PARTICULAR CHARACTERISTIC OF CANDIDATE SITES AND ARE USED TO COMPARE SITES TO ARRIVE AT A PREFERRED ORDER OR GROUPING 


\section{EXAMPLE OF GUIDELINES USED FOR SCREENING}

\section{OBJECTIVE: ASSURE PUBLIC HEALTH AND SAFETY}

\section{CONSIDERATION \\ A) NATURAL HAZARDS}

1) FAULT RUPTURE

b) HORIZONTAL AND VERTICAL DISTANCE FROM KNOWN FAULTS INTERPRETED TO BE NOT

CAPABLE AND ZONES OF

FRACTURING AND JOINTING

c) LOCATION WITH RESPECT TO LINEAMENTS AND POSTULATED FAULTS a) HORIZONTAL AND VERTICAL DISTANCE FROM KNOWN FAULTS INTERPRETED TO BE CAPABLE

\section{GUIDELINE}

a) INCLUDE AREAS > 5 MILES, HORIZONTALLY AND VERTICALLY, FROM KNOWN FAULTS INTERPRETED TO BE CAPABLE

b) INCLUDE AREAS >5 MILES, HORIZONTALLY AND VERTICALLY, FROM KNOWN FAULTS WHOSE CAPABILITY IS UNKNOWN WHICH HAVE LOW POTENTIAL FOR A CAPABILITY EVALUATION

a) INCLUDE AREAS >1/2 MILE FROM KNOWN FAULTS INTERPRETED TO BE NOT CAPABLE AND FROM ZONES OF FRACTURING AND JOINTING

b) INCLUDE AREAS > 1/2 MILE FROM KNOWN FAULTS WHOSE CAPABILITY IS UNKNOWN BUT WHICH HAVE A HIGH POTENTIAL FOR A CAPABILITY EVALUATION

EVALUATE AREAS ON BASIS OF PROXIMITY TO LINEAR FEATURES (LINEAMENTS) AS INTERPRETED FROM REMOTE SENSING AND GEOPHYSICAL DATA AND POSTULATED FAULTS 


\section{RELATIONSHIP OF AREA DESIGNATIONS}

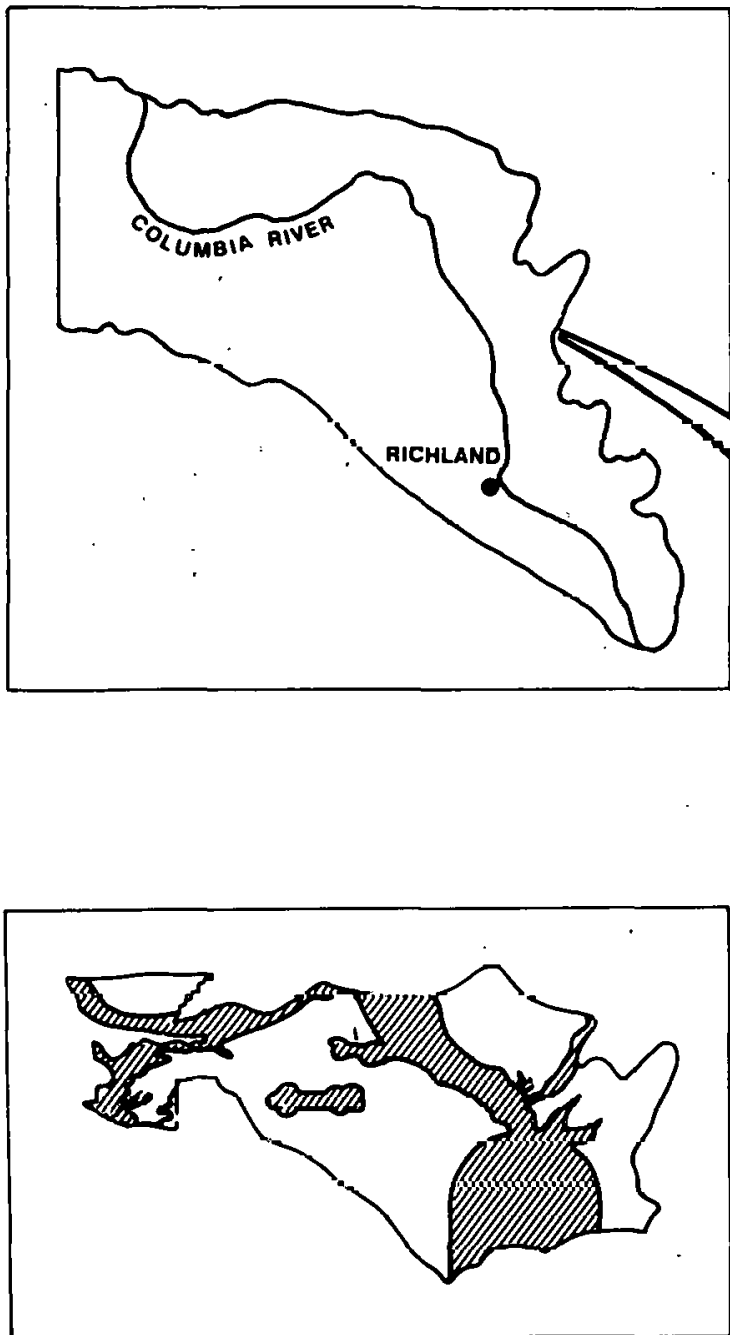

4 SUB-AREAS

PASCO BASIN SCREENING AREA
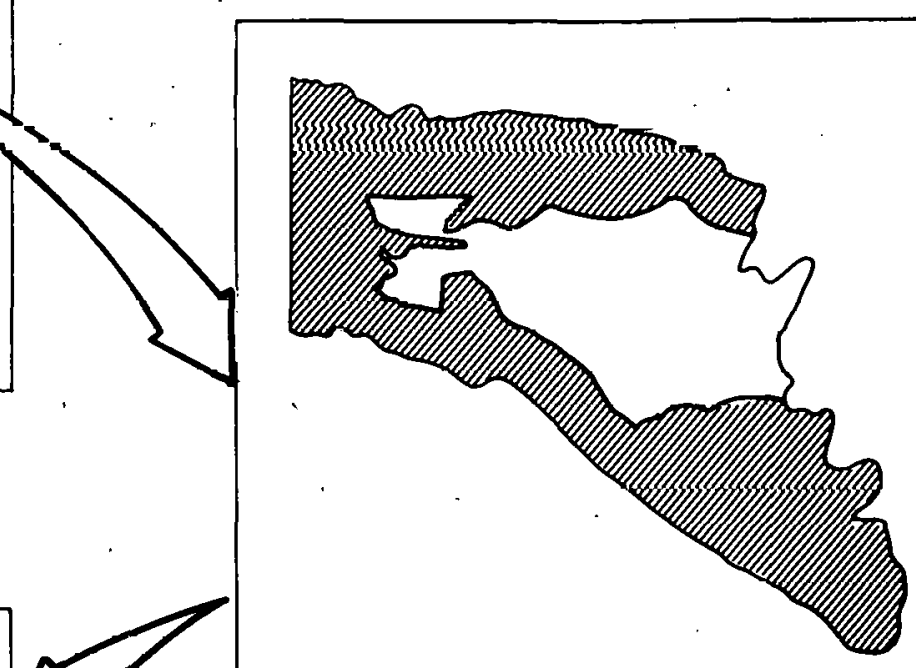

\section{CANDIDATE AREA}
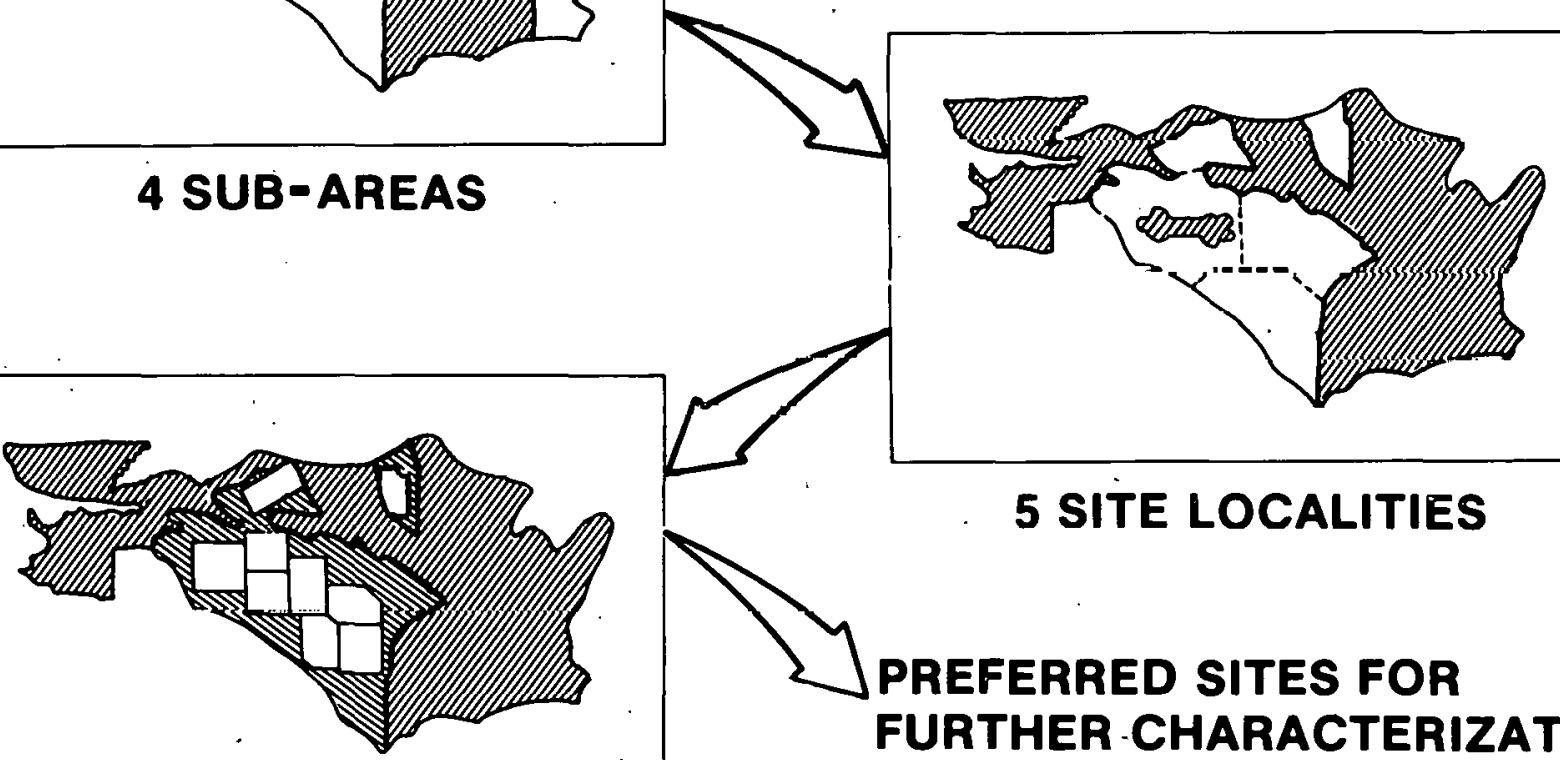

5 SITE LOCALITIES

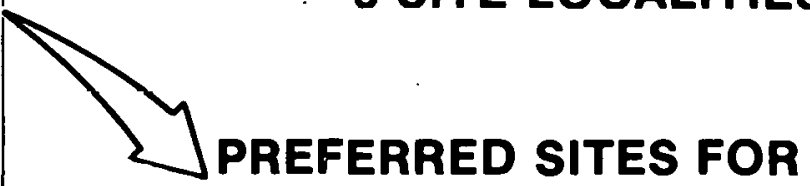

FURTHER -CHARACTERIZATION 


\section{THE OVERLAY PROCESS}

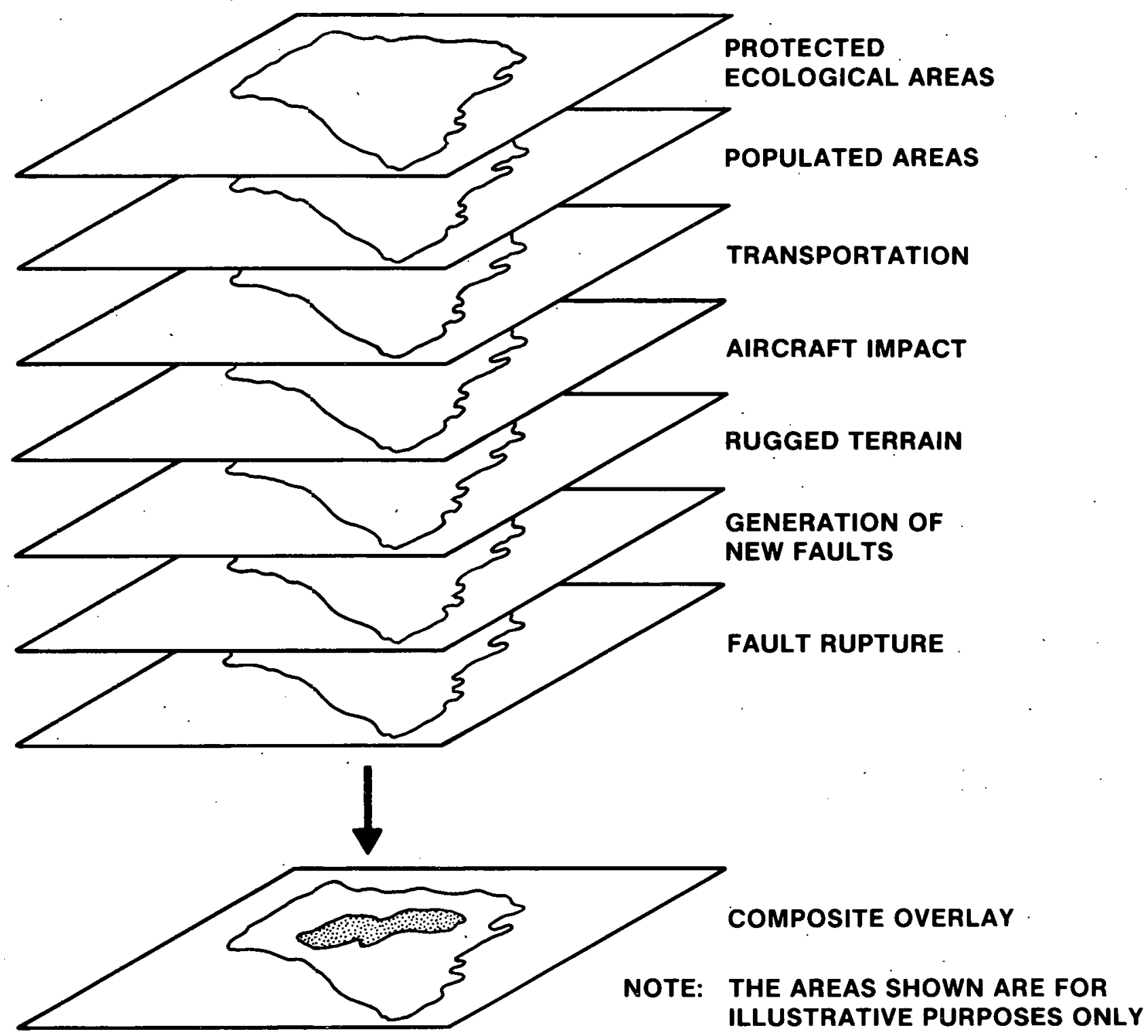




\section{DATA ASSEMBLY OBJECTIVE}

LOCATE, ACQUIRE AND SCREEN SOURCES OF PERTINENT DATA BASED ON THEIR PROBABLE UTILIZATION IN THE SITING PROCESS AND ALSO BASED ON READILY

AVAILABLE PUBLISHED AND UNPUBLISHED LITERATURE 


\section{EXAMPLE OF USE OF KEY WORD INDEX AND ANNOTATED REFERENCES DATA CATALOGING}

1. SAMPLE TOPIC

Internal structures of basalt flows

2. LOCATE THE MOST APPROPRIATE KEY WORD

KeY words are arranged in outline format

under major subject headings

\section{ENTRY IN KEY WORD INDEX}

\section{Intrabasalt structures}

$\begin{array}{llllll}143 & 150 & 184 & 201 & 283 & 447\end{array}$

4. TURN TOANNOTATED REFERENCES AND LOCATE THE REFERENCES WITH THE NUMBERS ON THE KEY WORD INDEX
143. Hodges, C. A., 2918, Bosaltic ring structures of the columbto Plateau Geologicel Society of Americo Bulletin. v. 89. p. 1281-1289. Tle ring structure found in the Rozo menber mear Odessa is described and festures are related to rising ground water as thick flows cooled wer - topographic low.

150. Hoyt, C. L., 1961. The Hemond S411-An intruston in the rakitas Basalt near menatchee, Moshington: Morthmest Science, v. 35, no. 2, p. 58-64. The basale structures in mestern Dougles County are discussed. "The Harmond sill is an Invasive sill with subsidiory dikes within the Rock Island interbed.

184. Long. P. E., 1978, Characterization and recognition of intraflow structures, Grande Ronde Baselt: Rockwell International, Informal Report RHO-BVI-LO-10, prepared for the U.S. Departient of Energy, Contract EY$n-c-06-1030$.

This report describes various intruflow structures in the Grande Ronde flows and thetr usefulness in correlating drill nole dota.

201. Mekee, 8., and Stradiling, D., 1970, The sag flowout: - newly described volcsnic structure: Geological Soclety of America Bulletin, v. 81. p. 2035-2014.

This orticle describes the ring structures occurring in the Roze Mentiber near Odessa, Mashington. They were formed by flutd lave escaping along concentrtc dikes in the partly solldified now.

283. Ryen, M. P., end Samaies, C. 6., 1978, Cycifc frecture mechanisem in cooling basalt: Geological society of America Bulletin, v. 89. p. 1295. 1308.

This paper addresses the question of how hexagonal polythedra are found and how verticol jolnts grow longer (crack tip deformation) in cooling basaits.

MT. Maters, A. C., 1960s, Deteraining direction of flow in baselts: Merican Journal of Sclence, v. 258-A, p. 350-366.

A deternination of flow olrection using columbar joints, sptracles. plpe vesicles und cyilinders. and priasry foreset bedaing in pologonite. 


\section{SCREENING AND IDENTIFICATION}




\section{CONSIDERATIONS USED IN SCREENING FOR CANDIDATE AREA}

- tRANSPORTATION

- OPERATIONAL RADIATION RELEASE

- AIRCRAFT IMPACT

- FAULT RUPTURE

- GENERATION OF NEW FAULTS

- GROUND MOTION

- PROTECTED ECOLOGICAL AREAS

- SITE PREPARATION COSTS (TERRAIN RUGGEDNESS) 


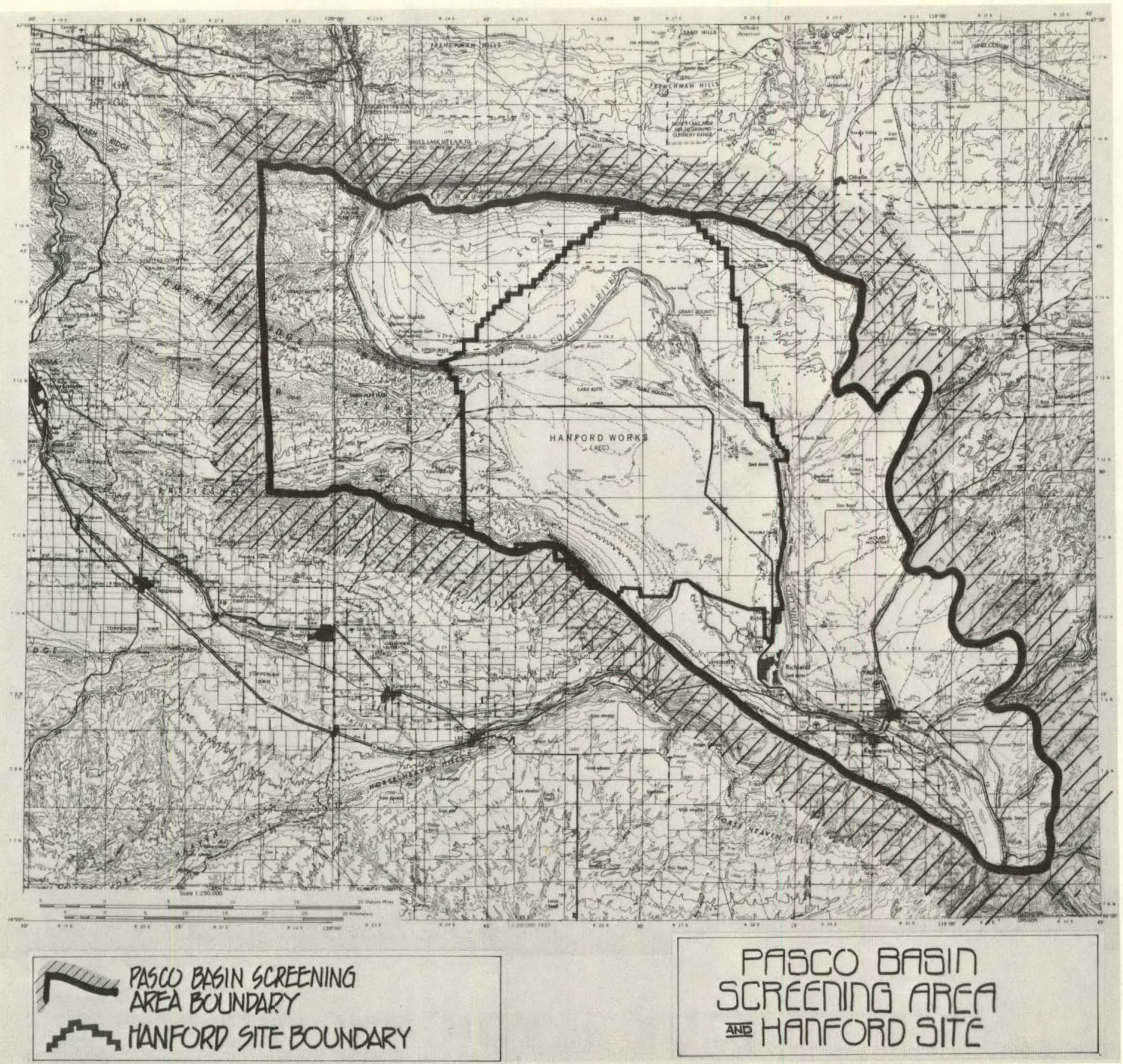




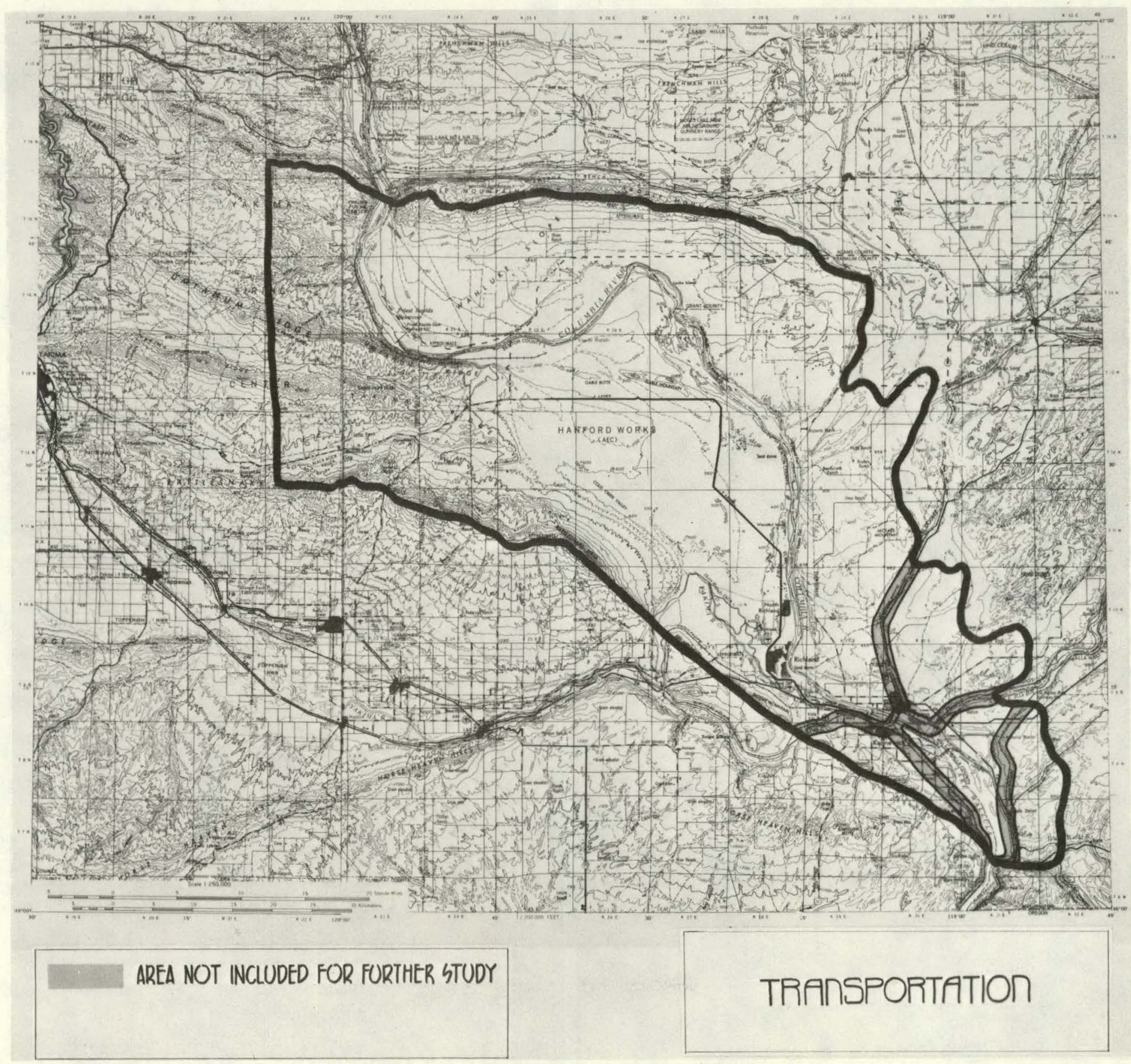

DOE Richland, WA 


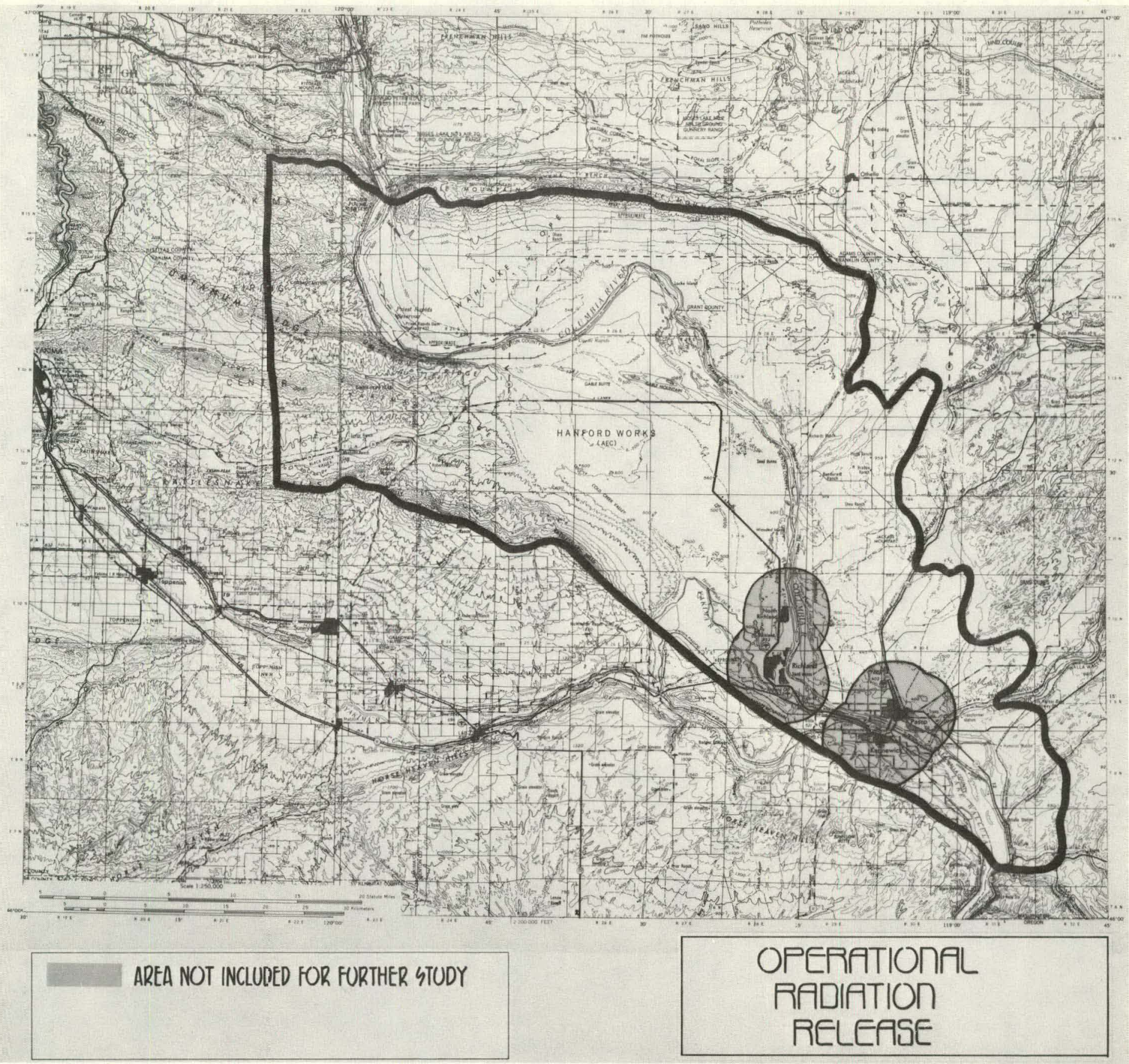




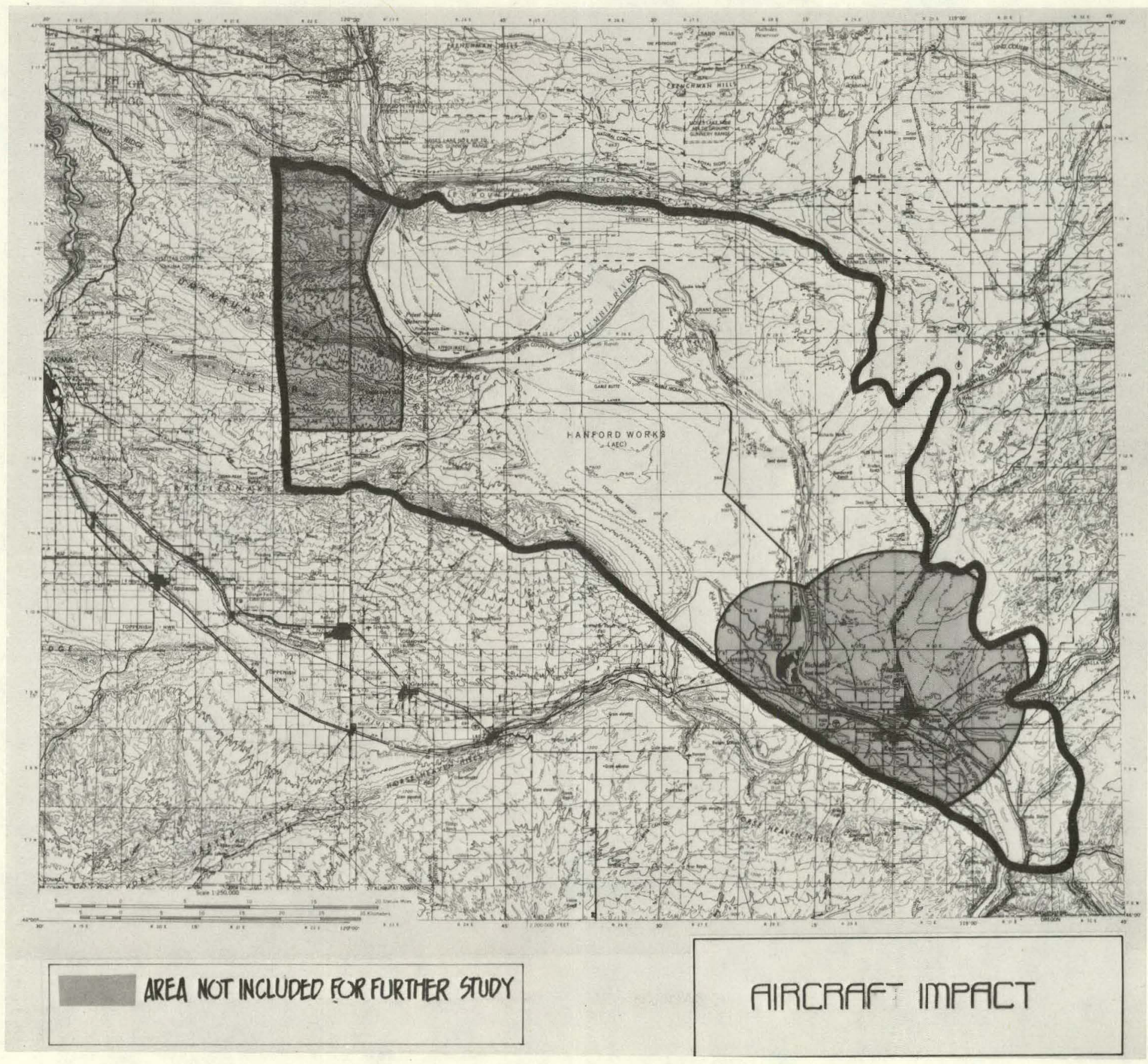




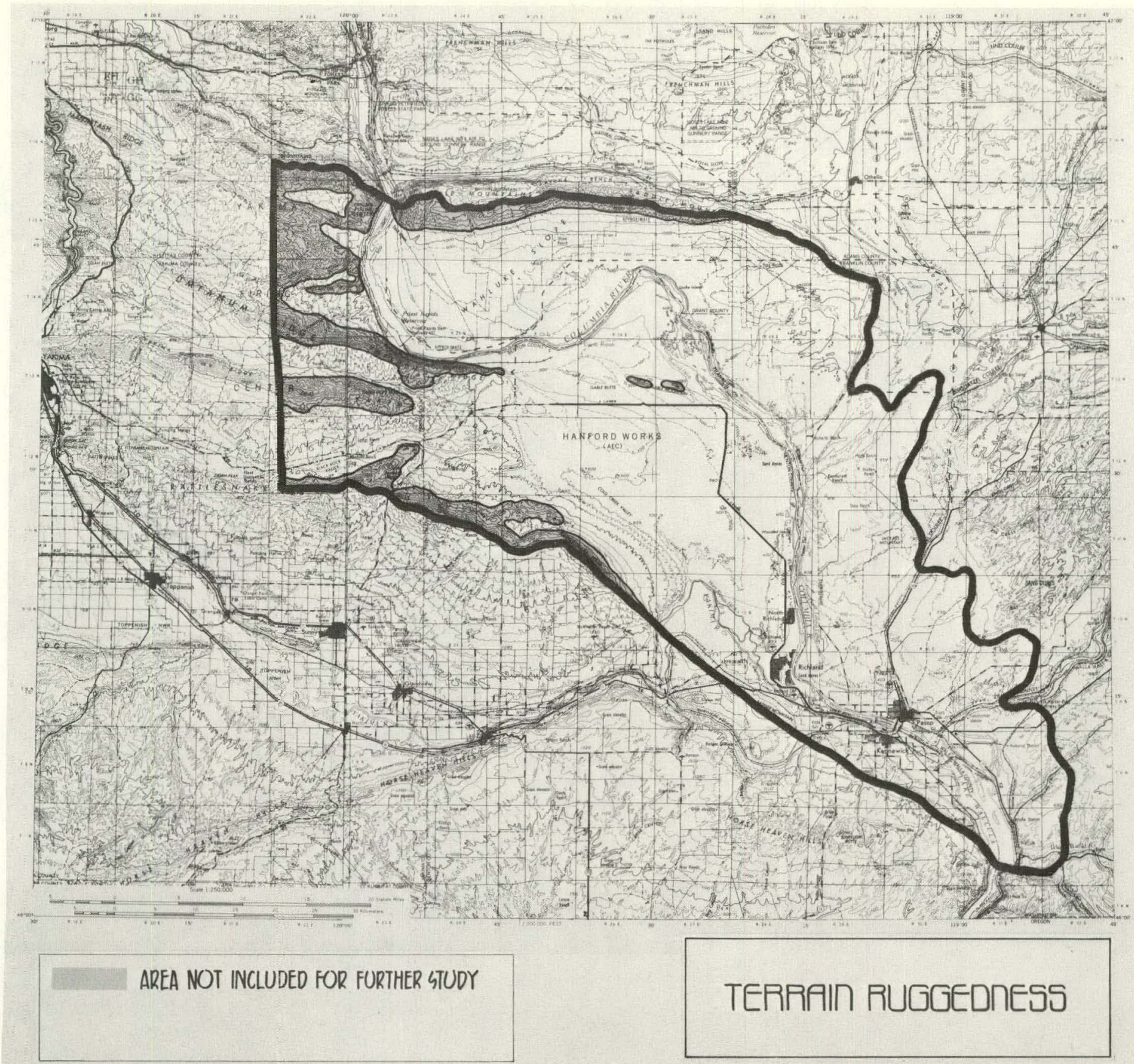




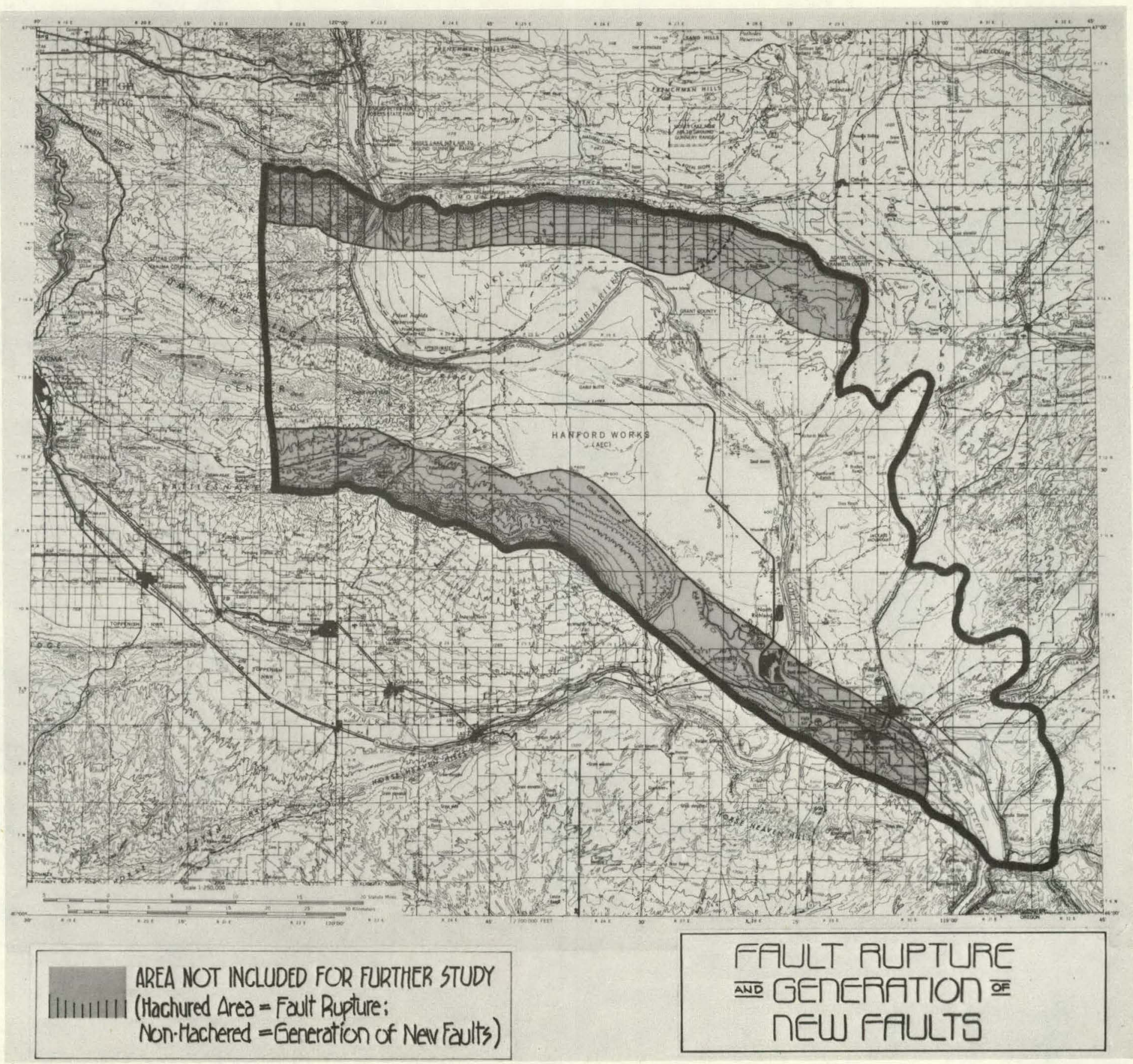




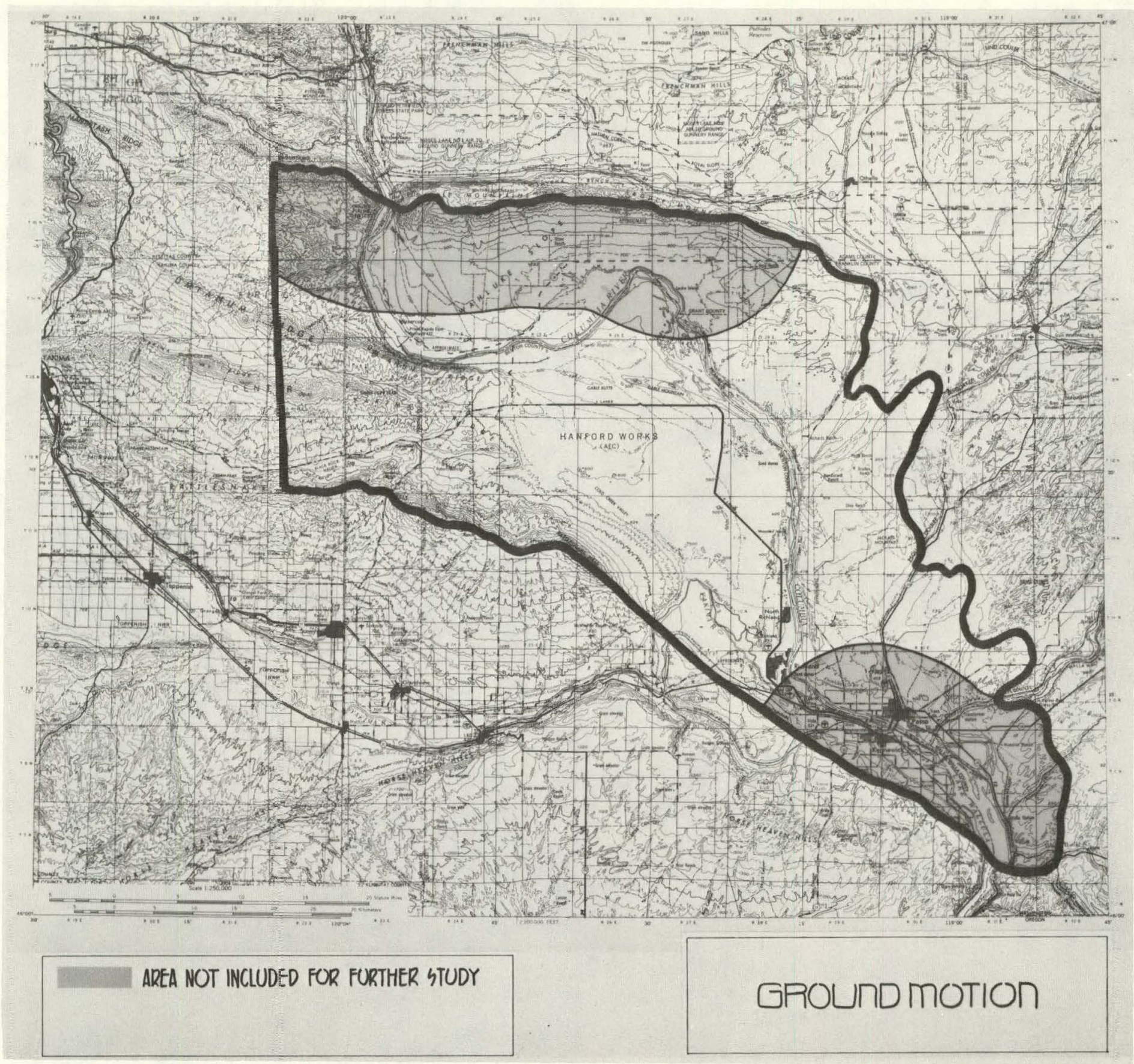




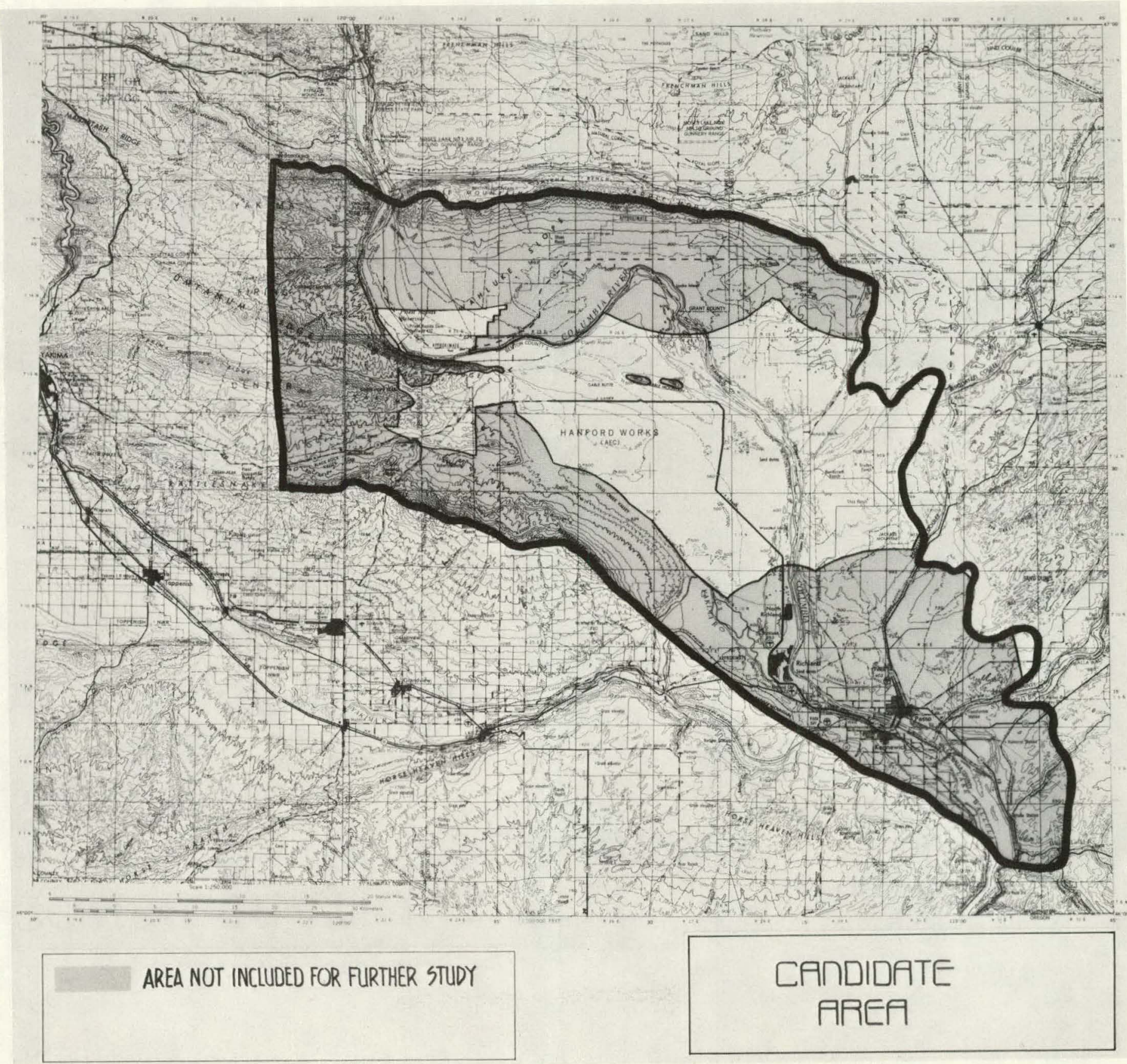




\section{CONSIDERATIONS USED IN SCREENING FOR SUB-AREAS}

- FAULT RUPTURE

- FLOODING

- GROUND FAILURE

- EROSION/DENUDATION

- SEPARATION FROM DEFENSE FACILITIES

- INDUCED SEISMICITY

- Site PREPARATION 


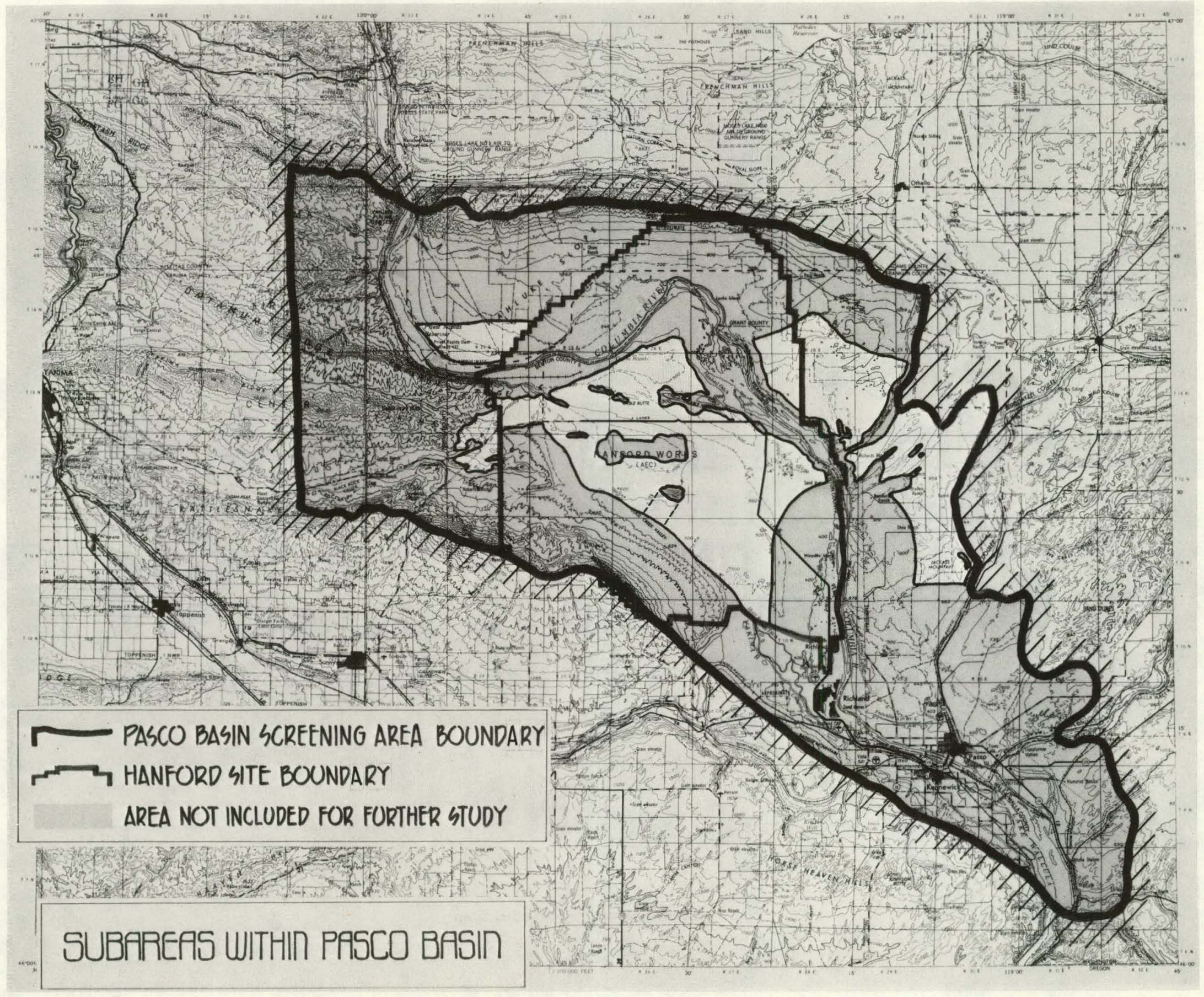


NO SUB-AREA WITHIN THE SCREENING AREA, BUT OUTSIDE THE HANFORD SITE BOUNDARY, WAS FOUND TO BE TECHNICALLY SUPERIOR TO THE SUB-AREAS WITHIN THE HANFORD SITE 


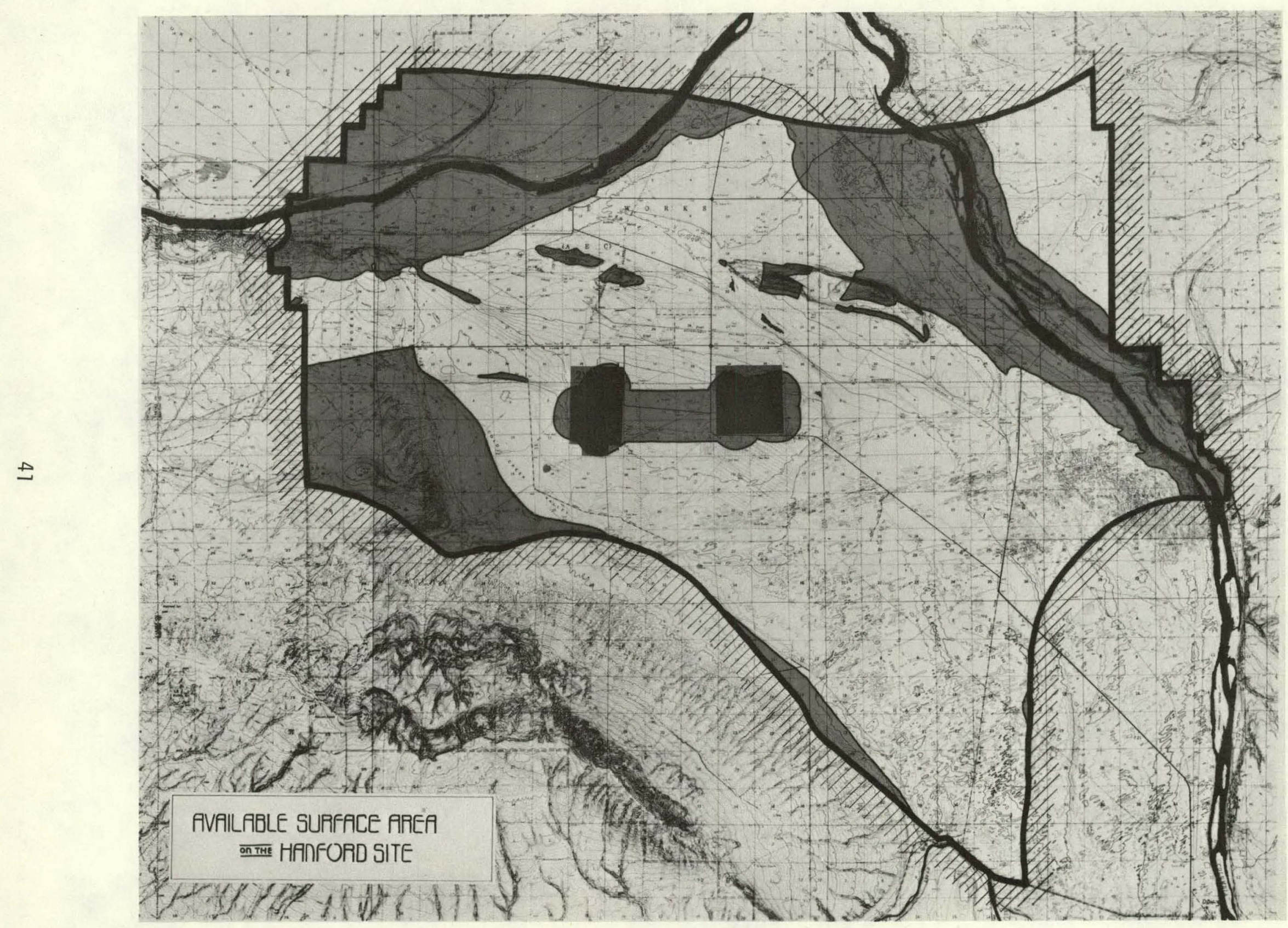




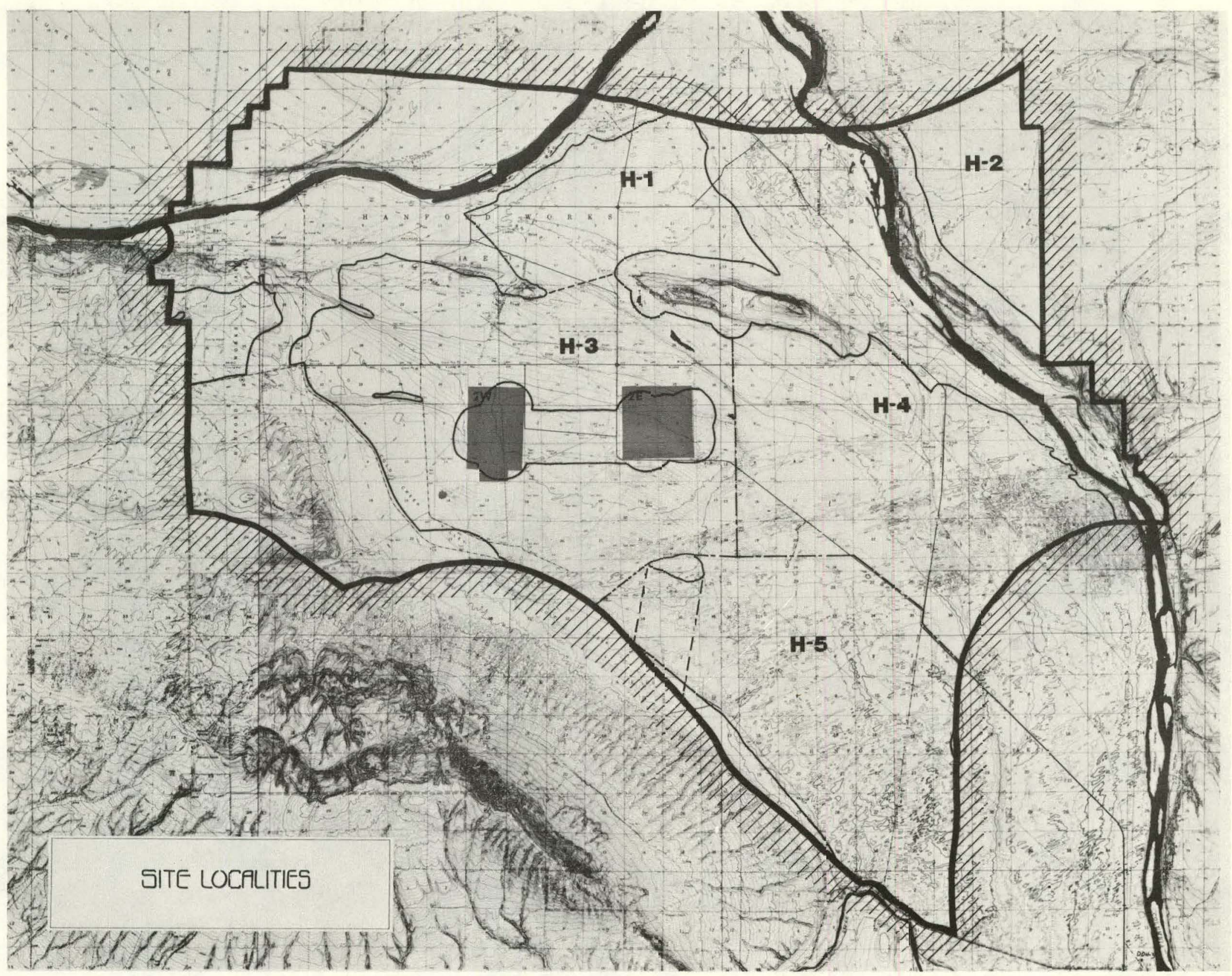


GEOLOGICAL SUPPORT 
RH0-BWI-LD-22

\section{AREAS OF BASALT EXPOSURE}

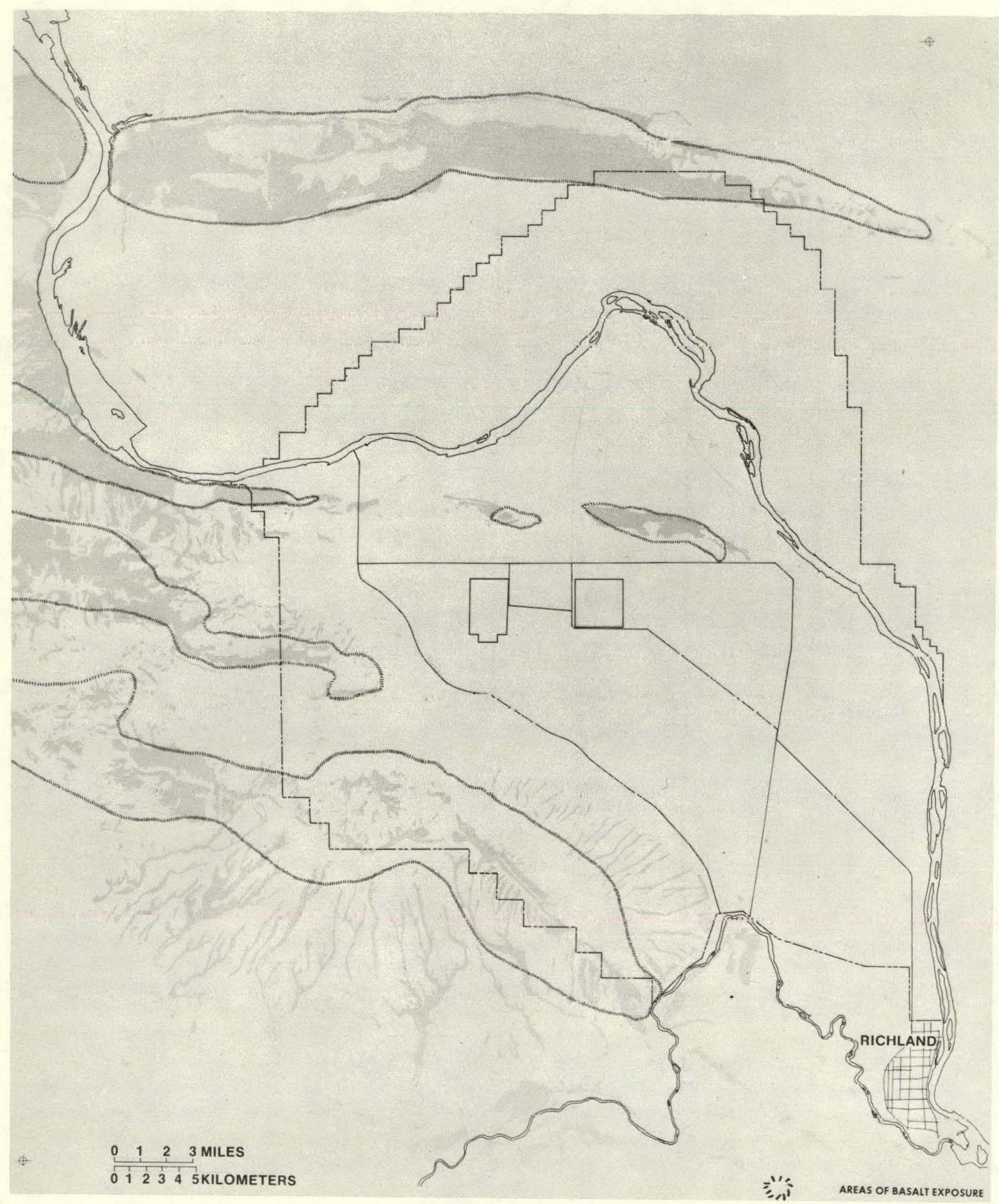


RHO-BW I-LD-22

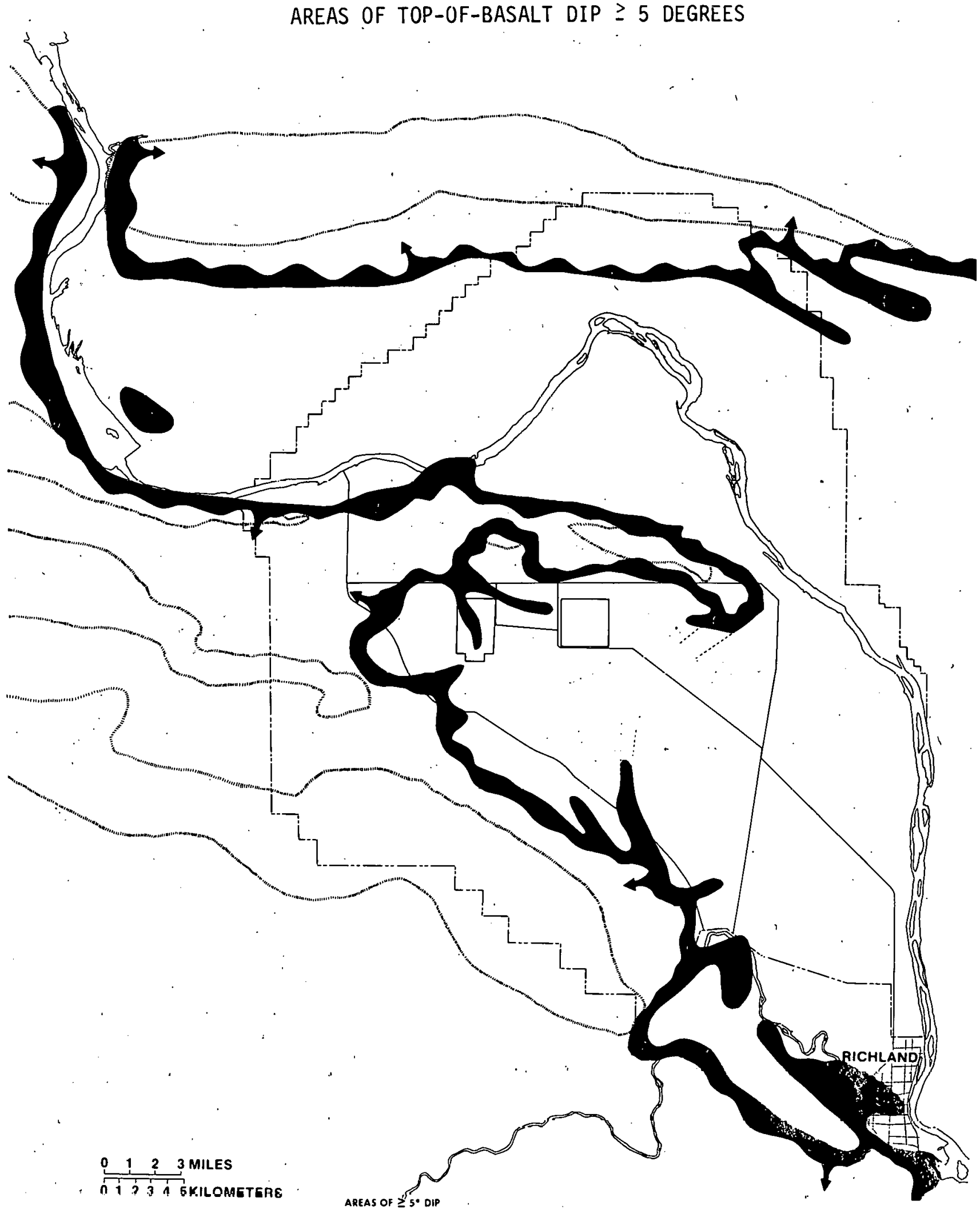


RHO-BWI-LD-22

FOLDING IN THE PASCO BASIN

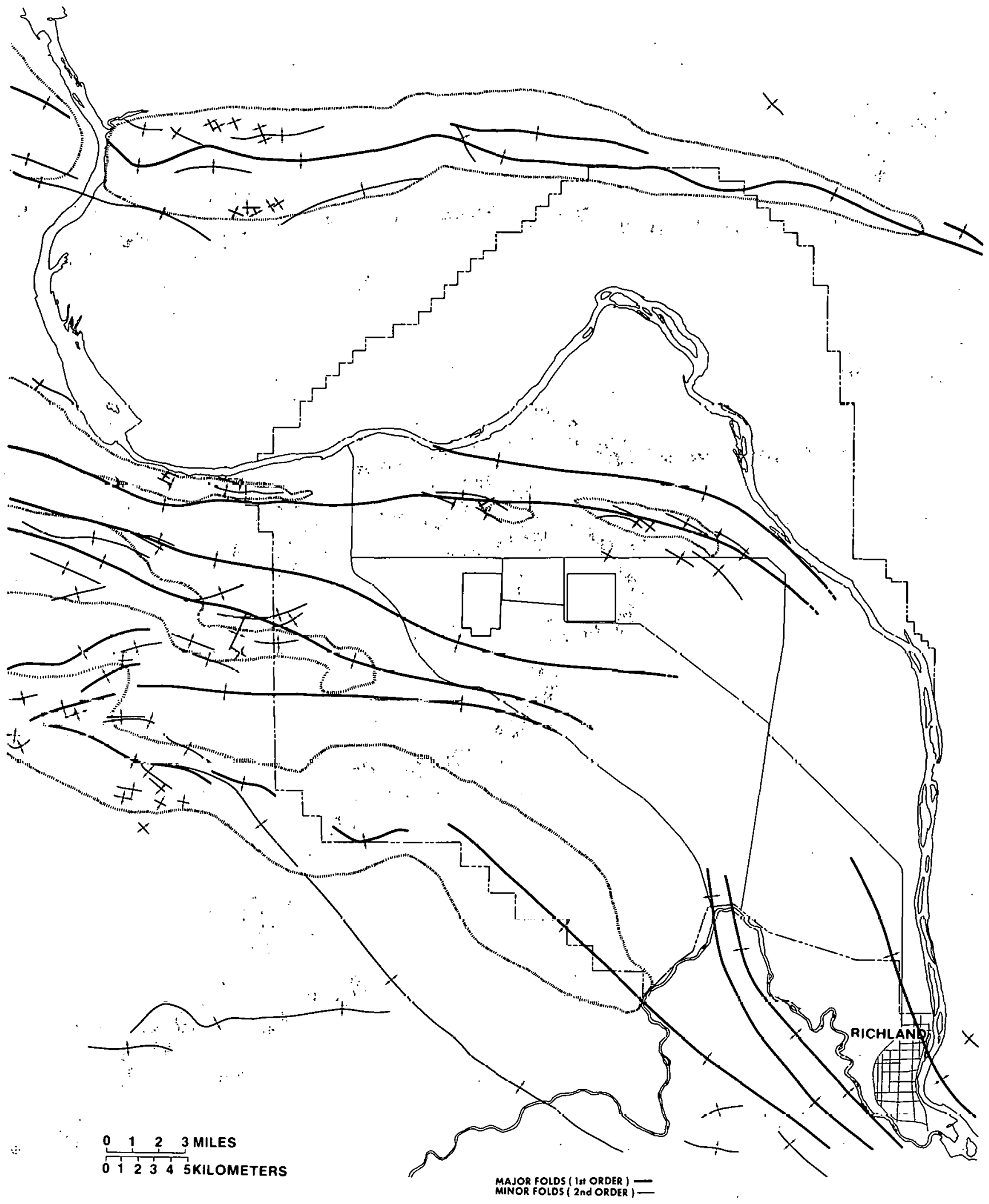

DOE Richland, WA 
FAULTING IN THE PASCO BASIN .

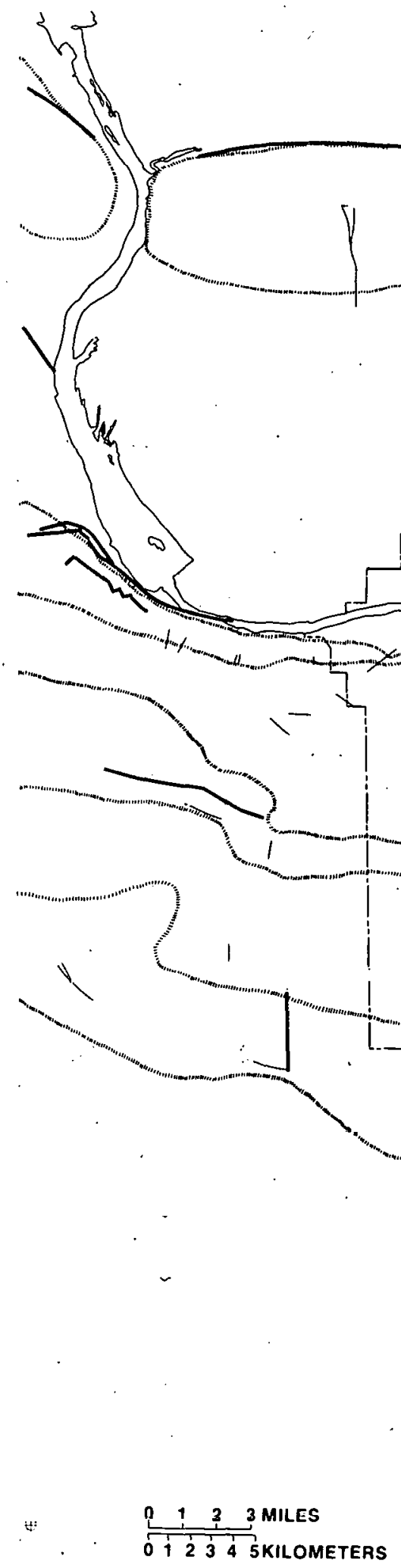

DOE 
RADIATION ZONES WITHIN THE HANFORD SITE

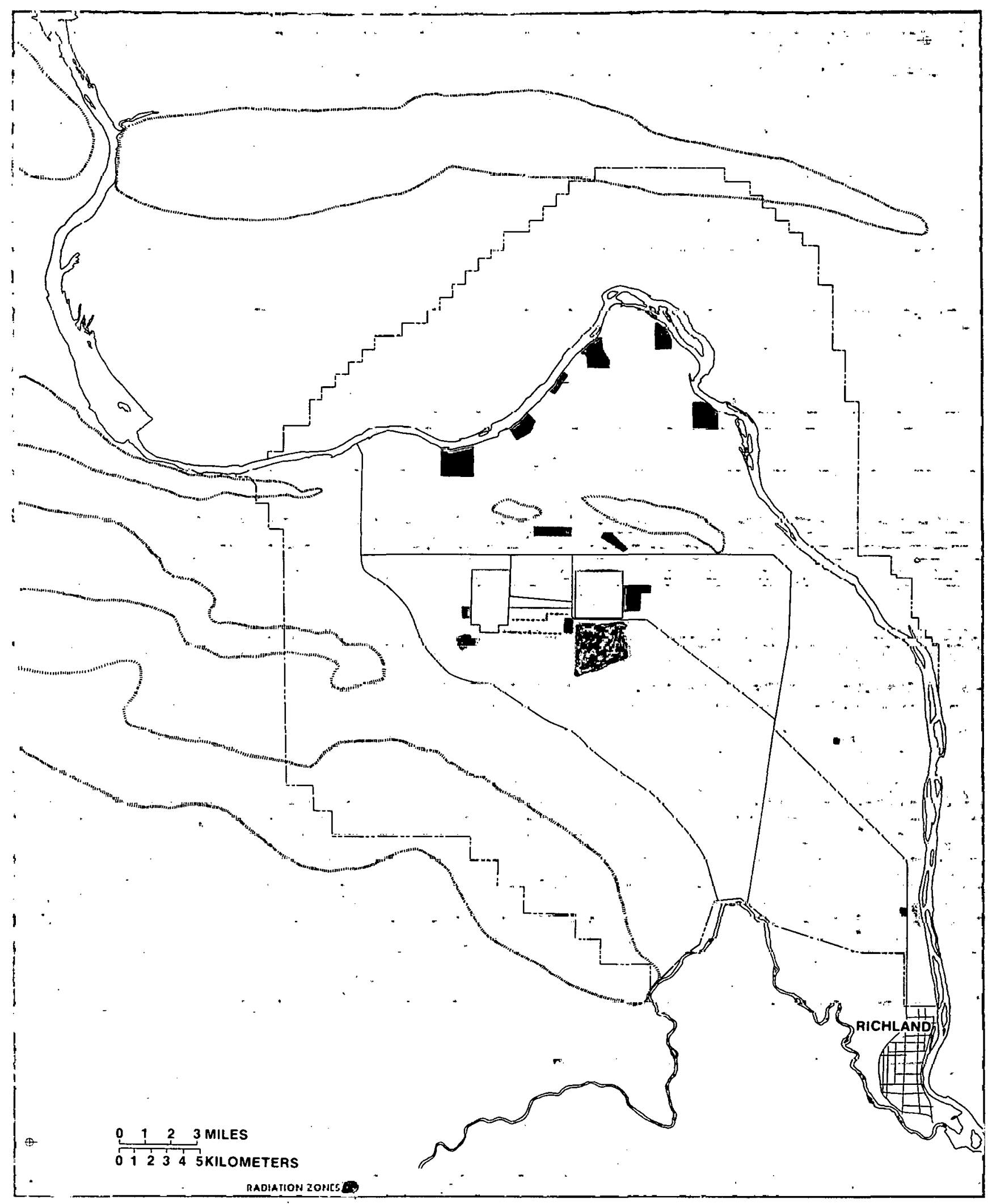

Dot micniand, Wa 
RH0-BWI-LD-22

GEOPHYSICAL SURVEY SITES

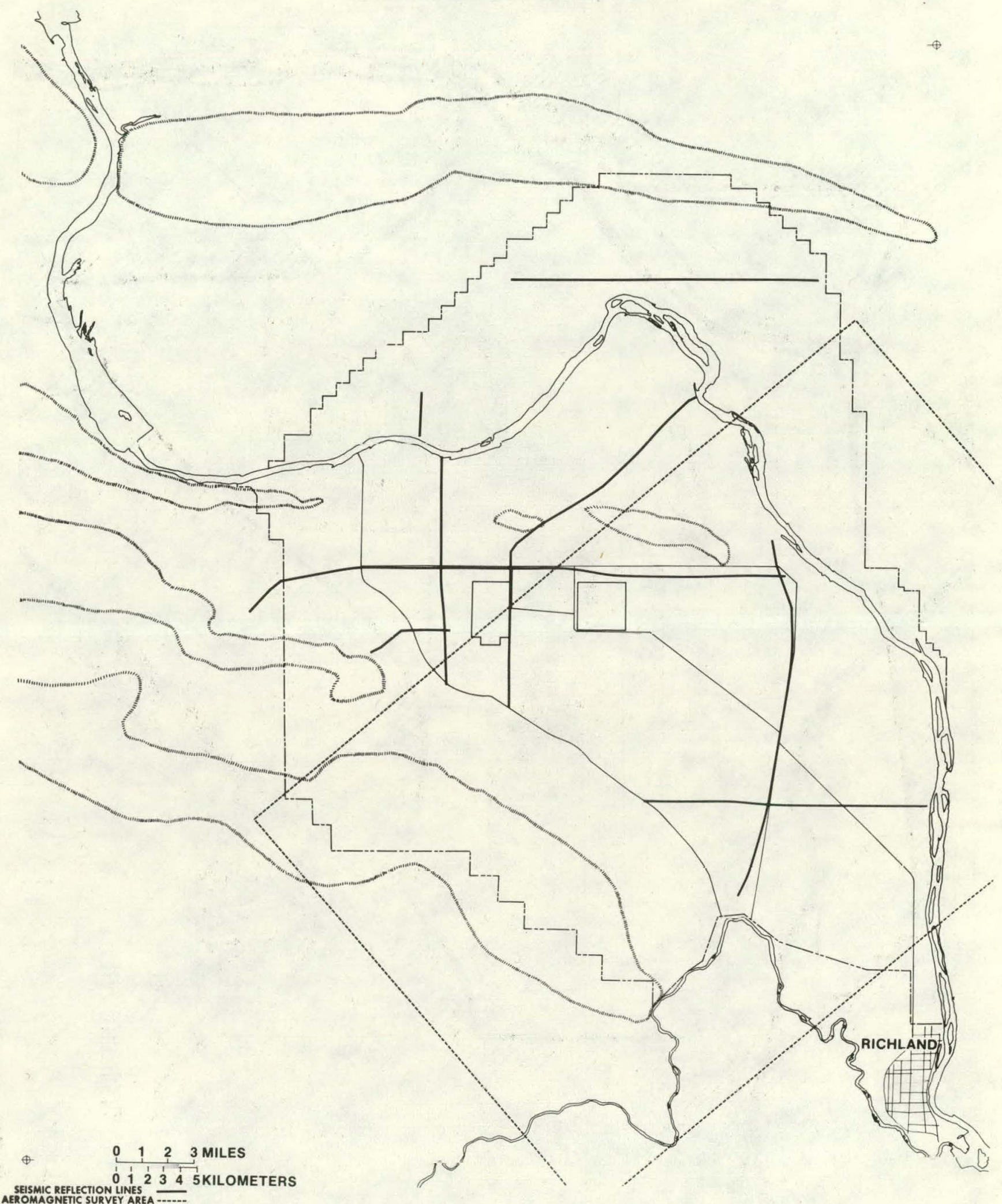

DOE Richland, WA 


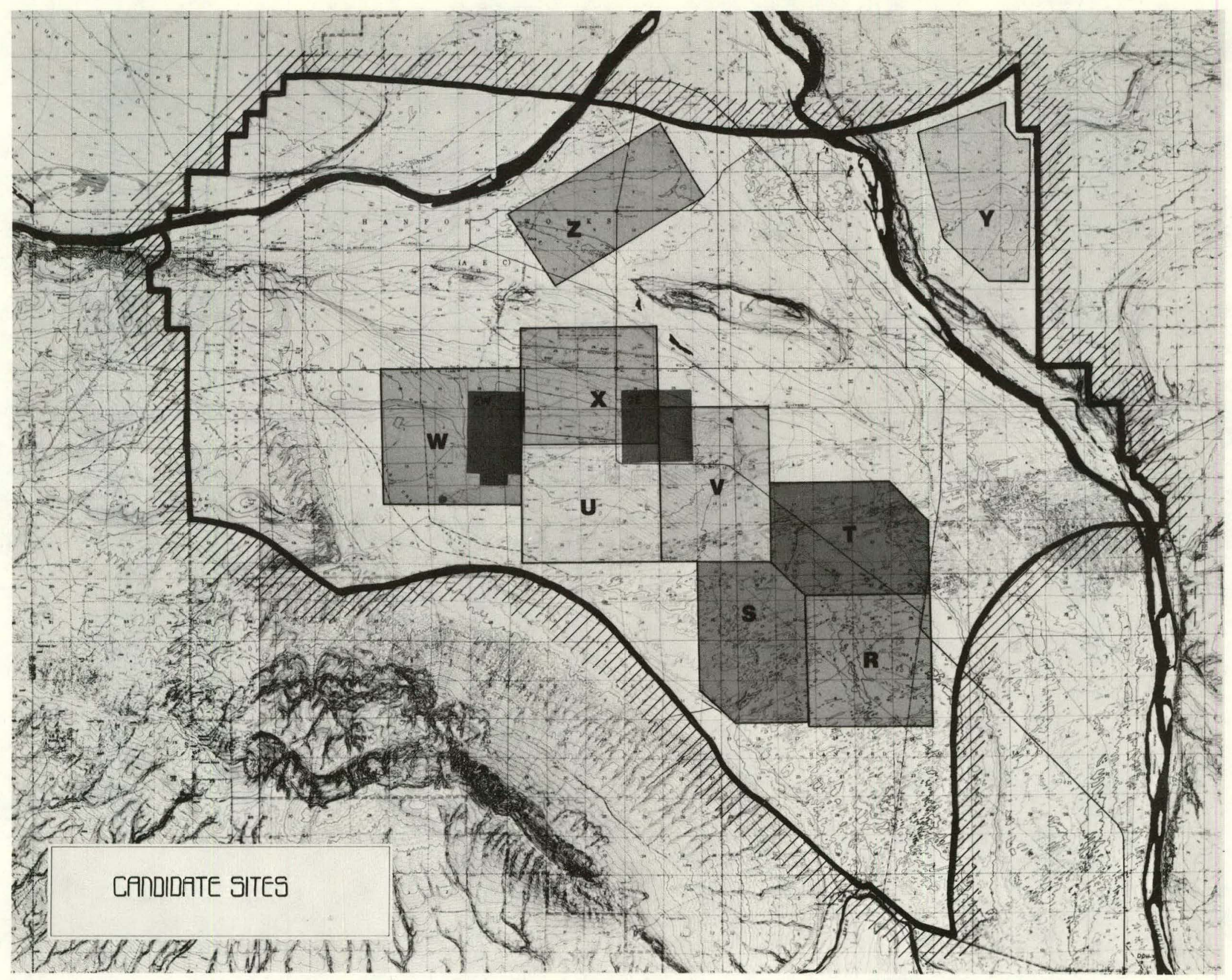




\section{APPROXIMATE PERCENTAGE OF LAND USE FOR REPOSITORY SURFACE FACILITIES}

TOTAL 1,425 acres

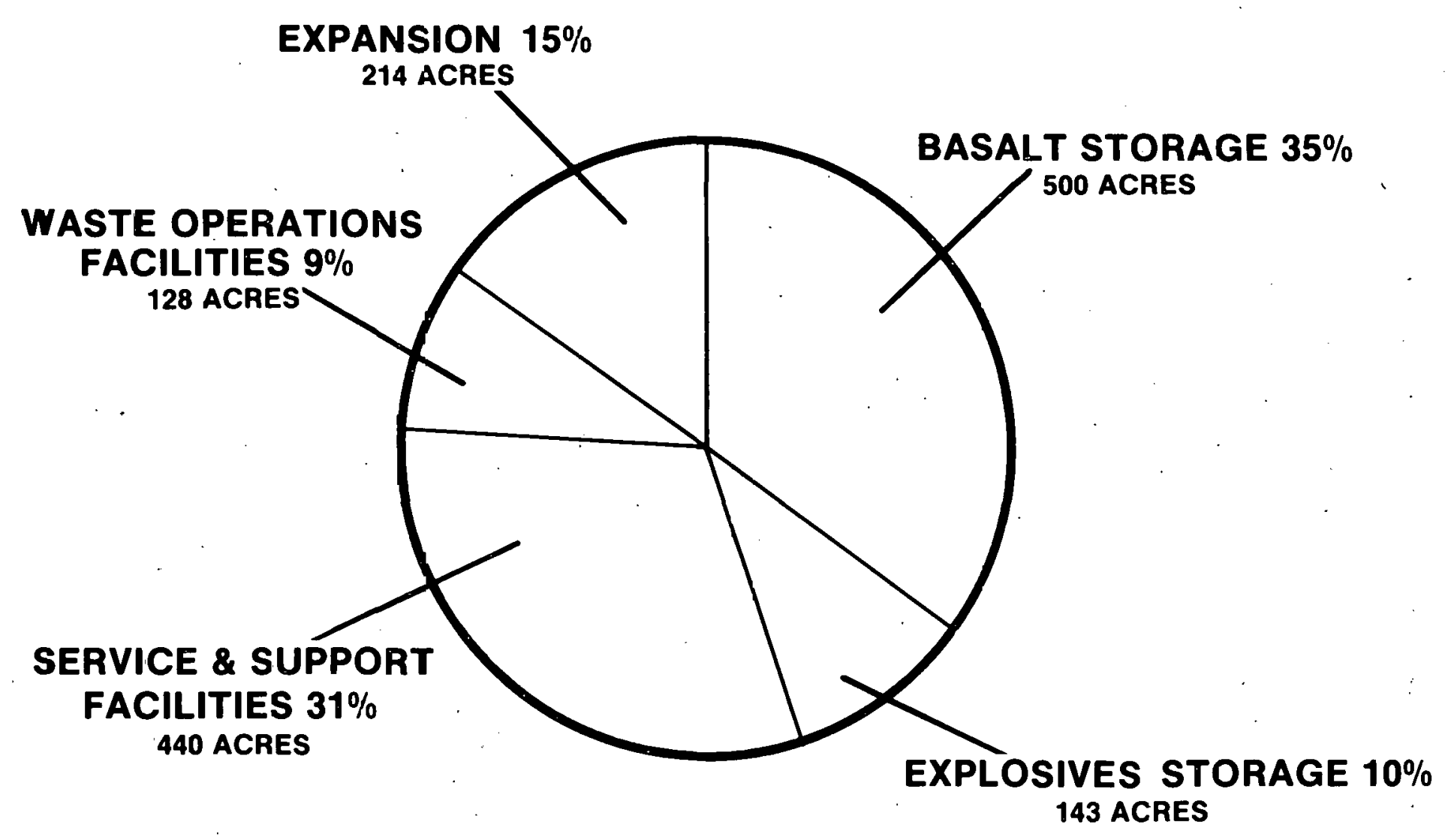




\section{PRECONCEPTUAL REPOSITORY SURFACE FACILITIES}

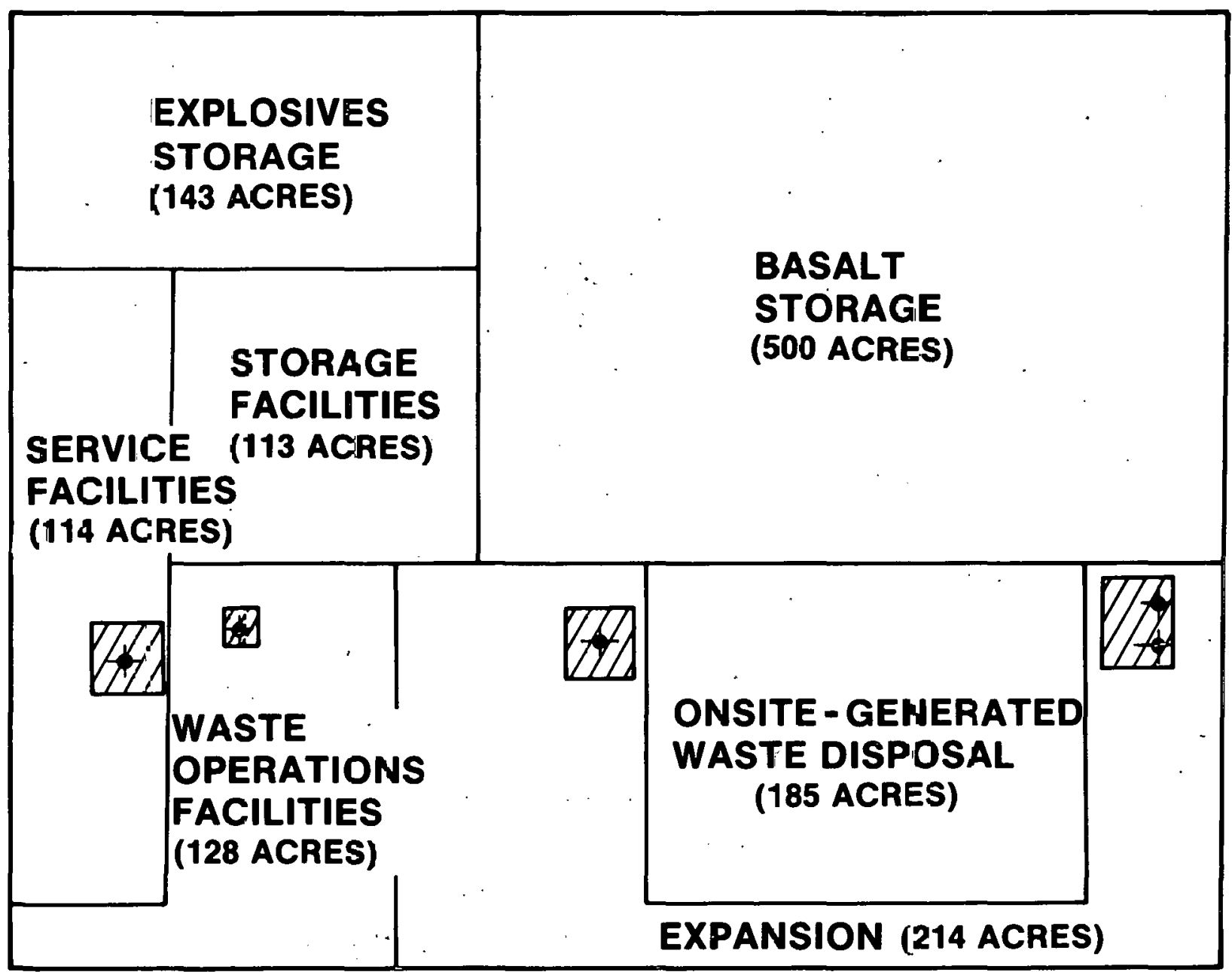

1.6 MILES

ID SHAFT HEAD FACILITIES

$\downarrow$ SHAFT

NOTE: SHAFT HEAD FACILITIES TOTAL 28 ACRES 


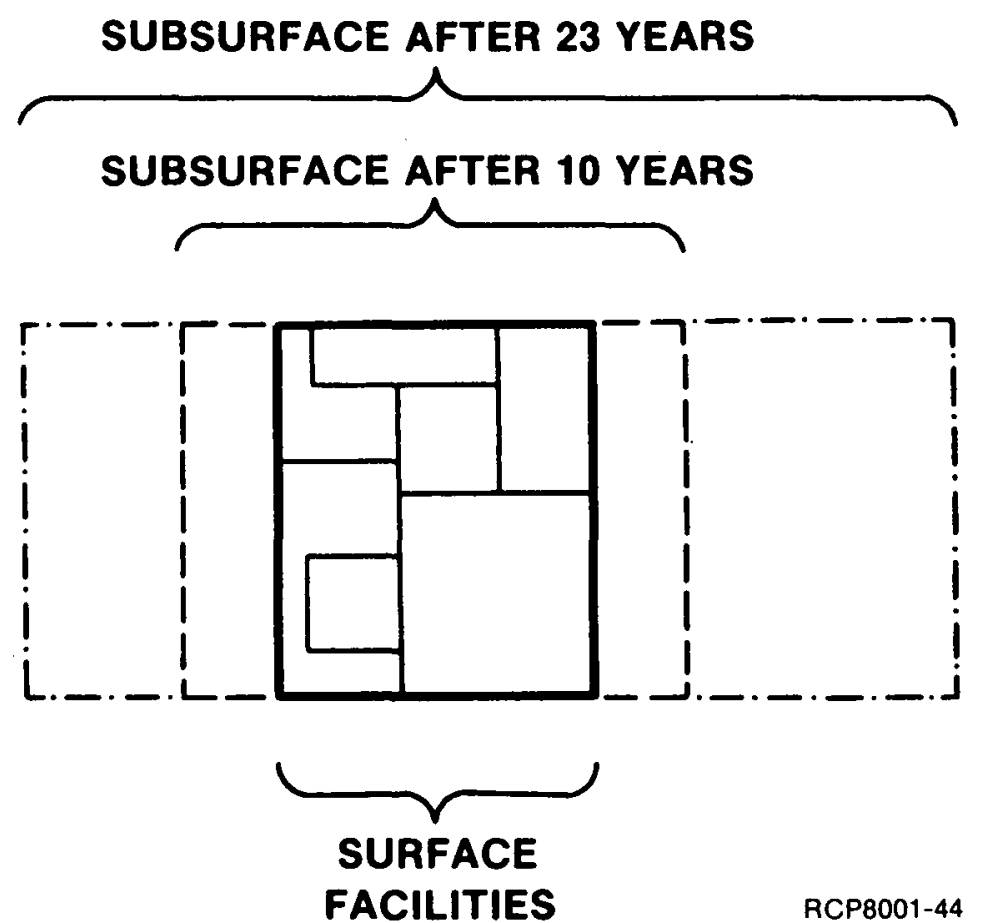


CANDIDATE SITE R
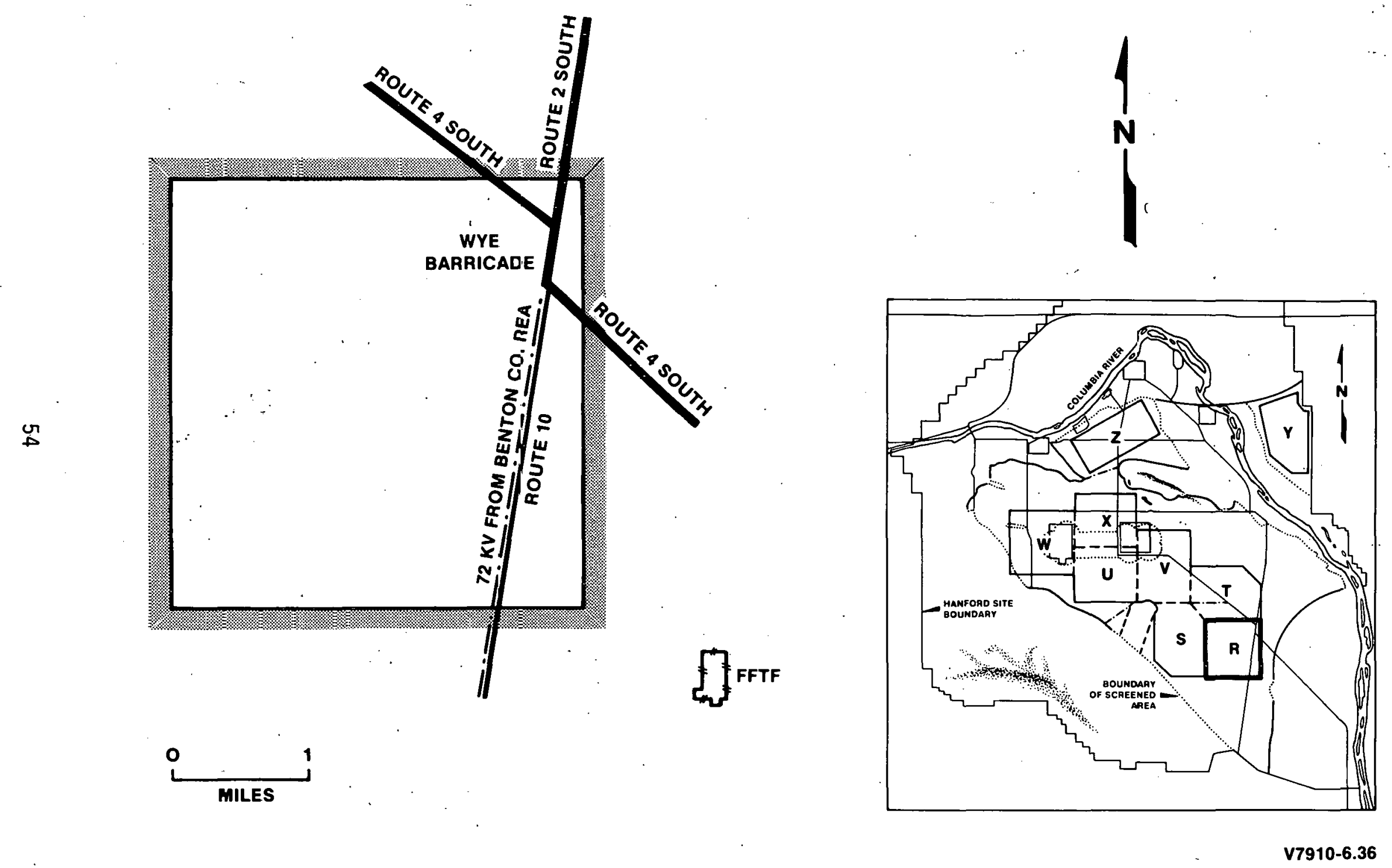

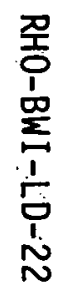




\section{CANDIDATE SITE S}
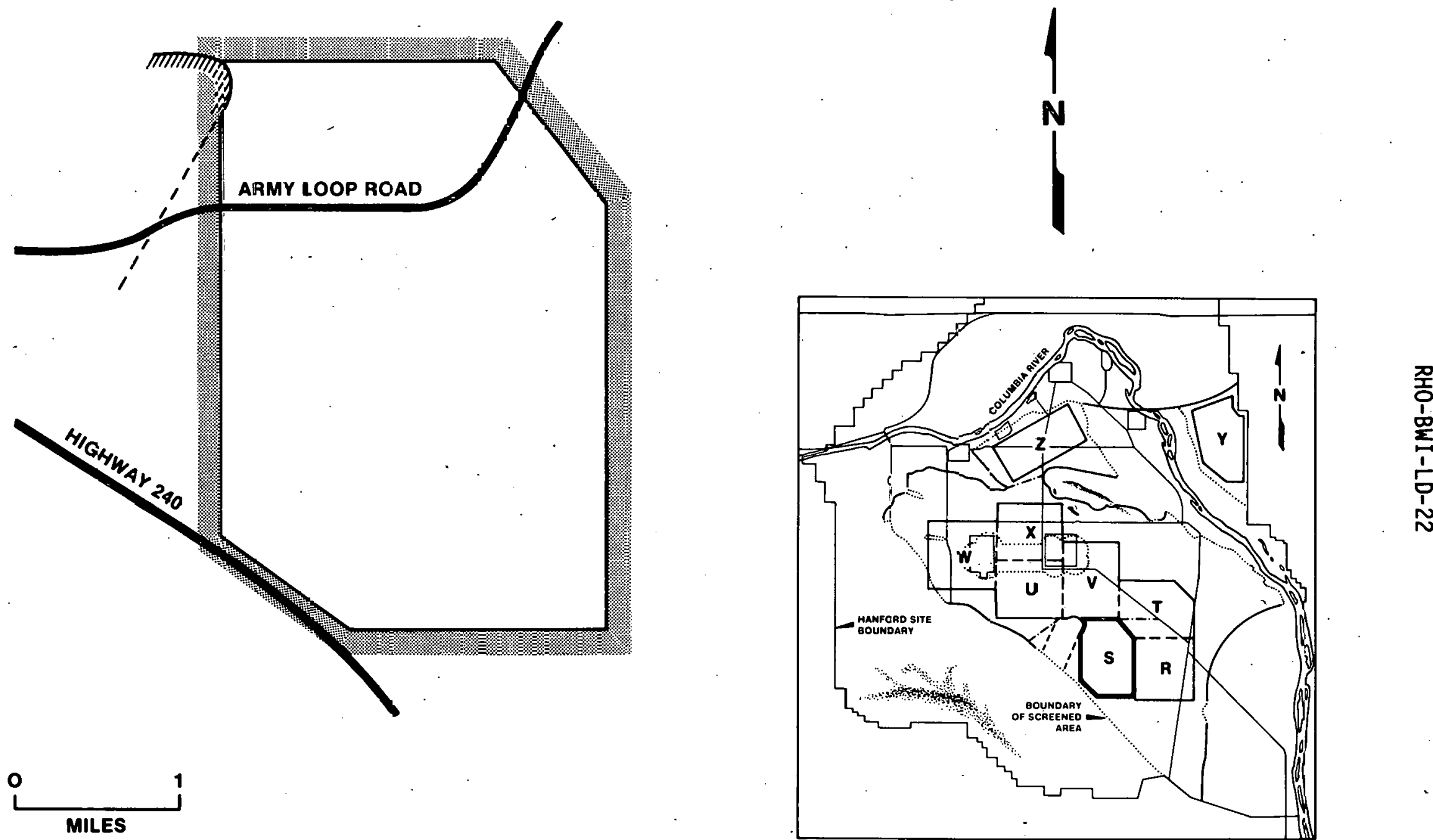

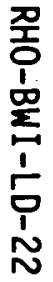




\section{CANDIDATE SITE T}
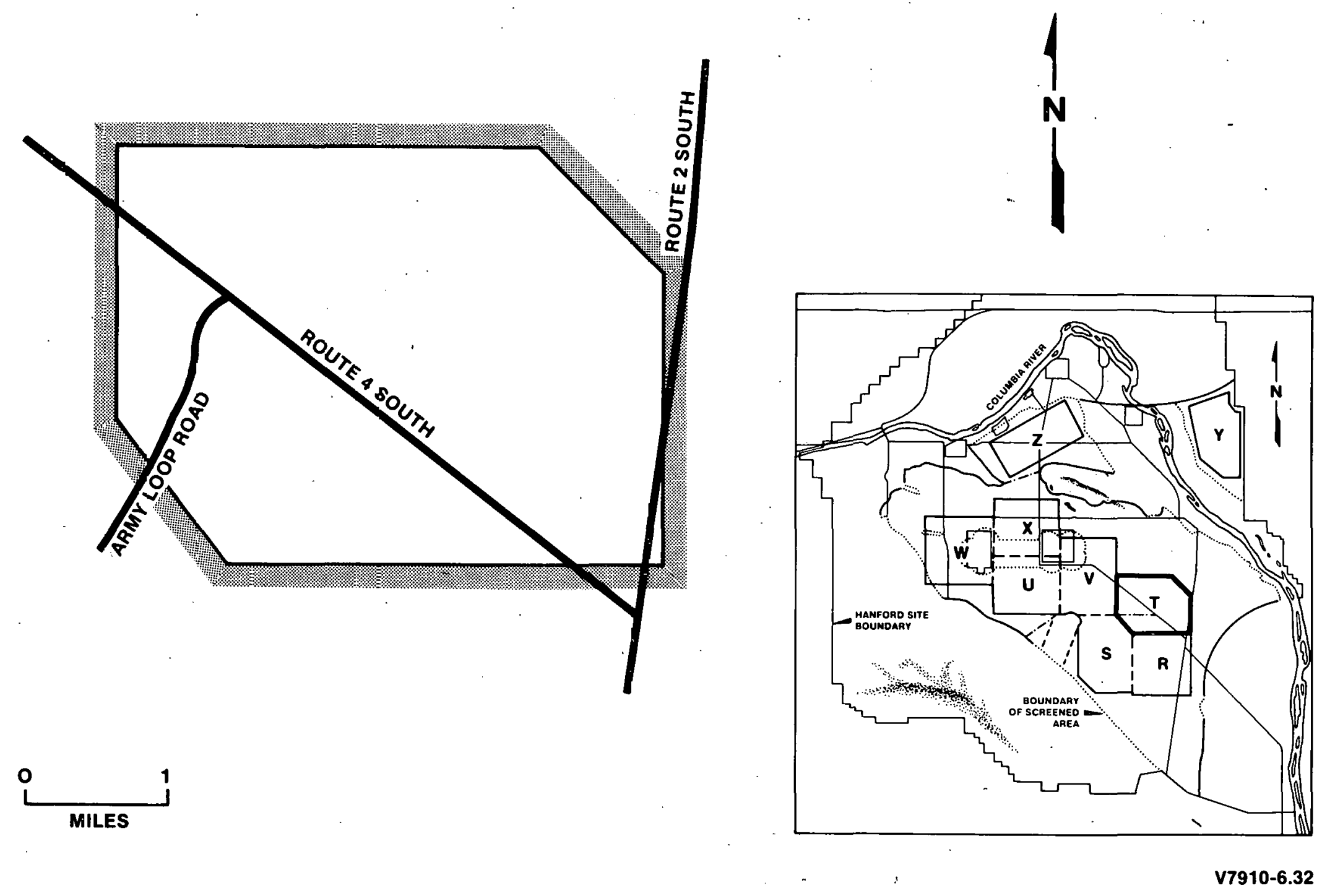


\section{CANDIDATE SITE U}
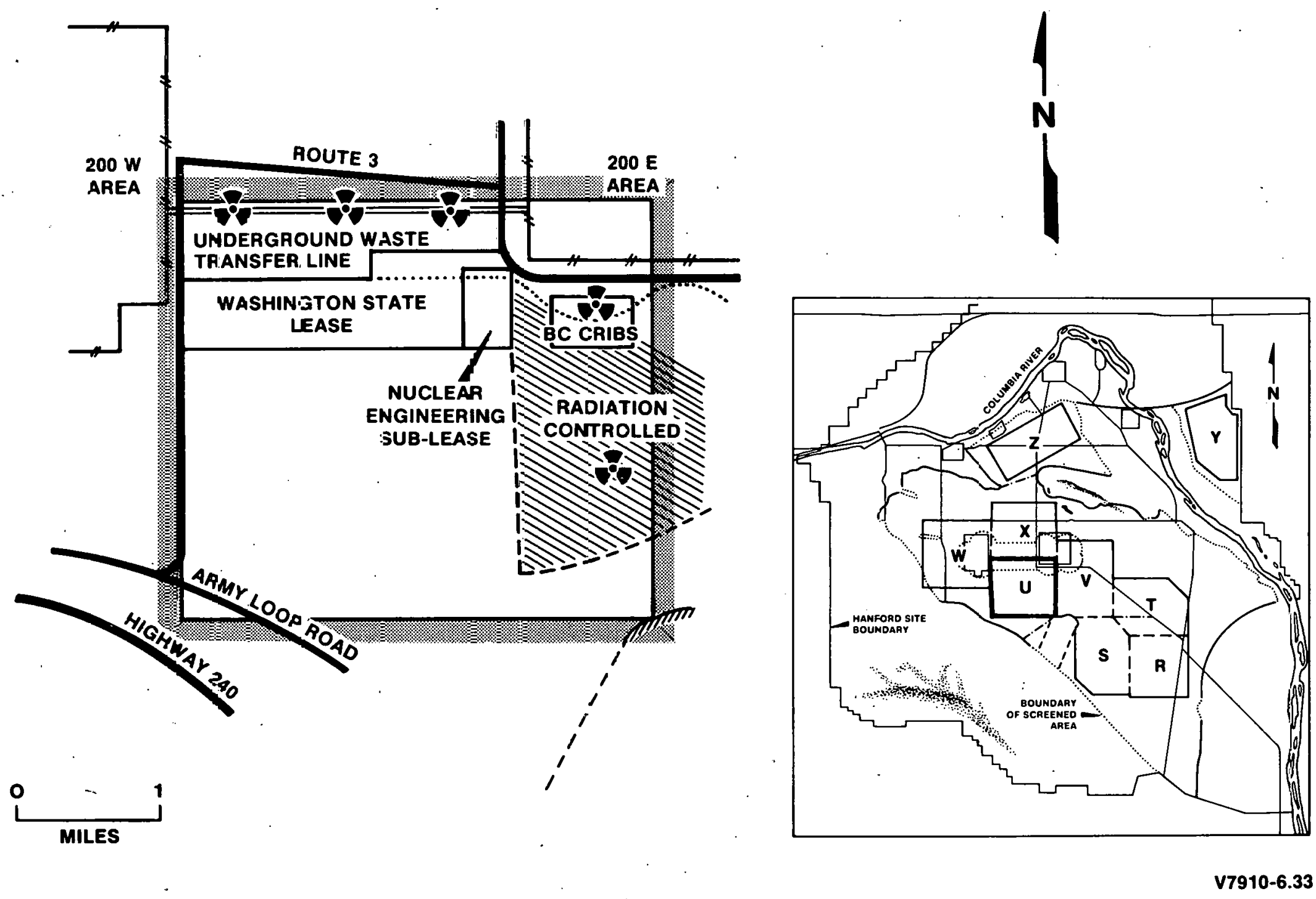


\section{CANDIDATE SITE V}
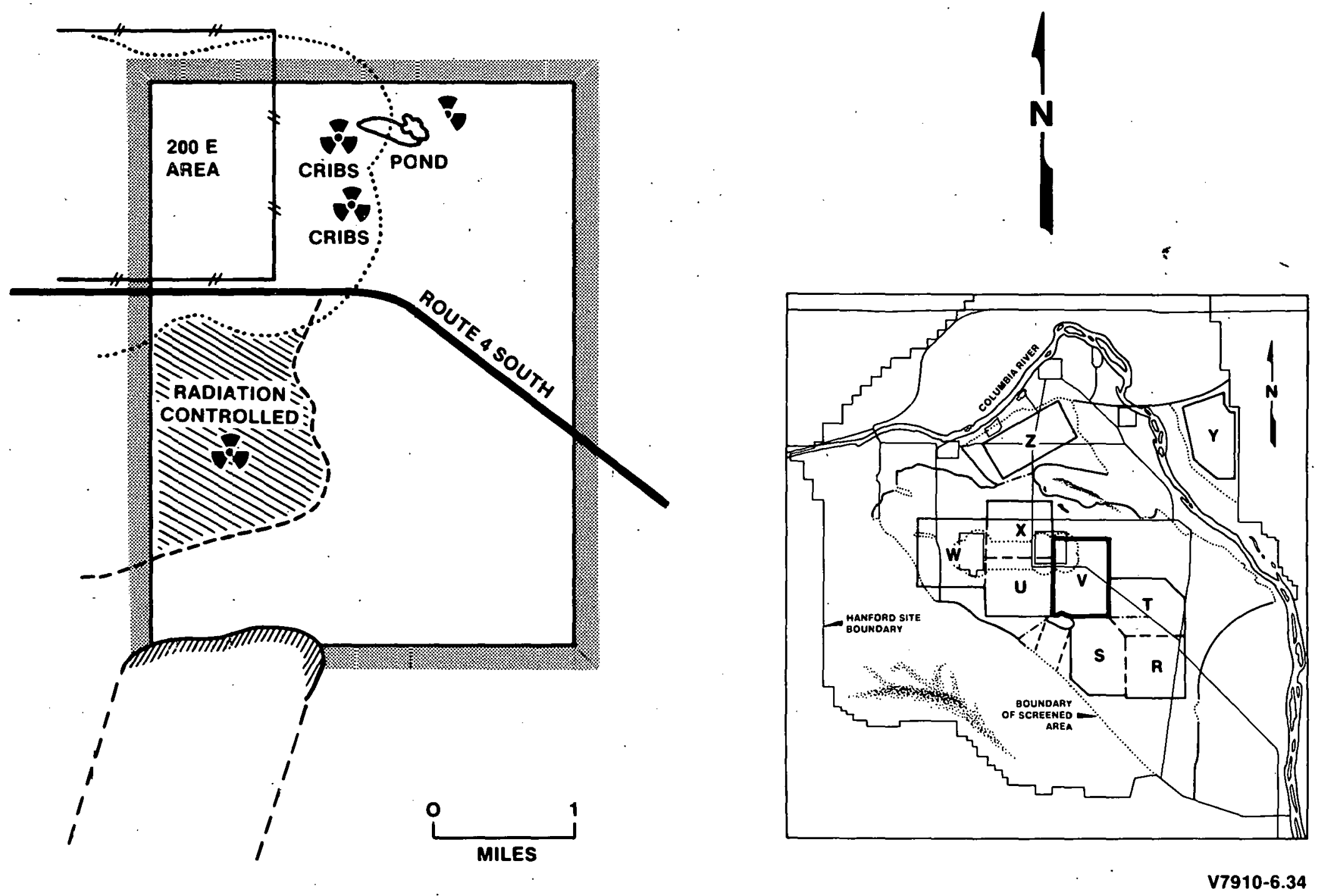


\section{CANDIDATE SITE W}
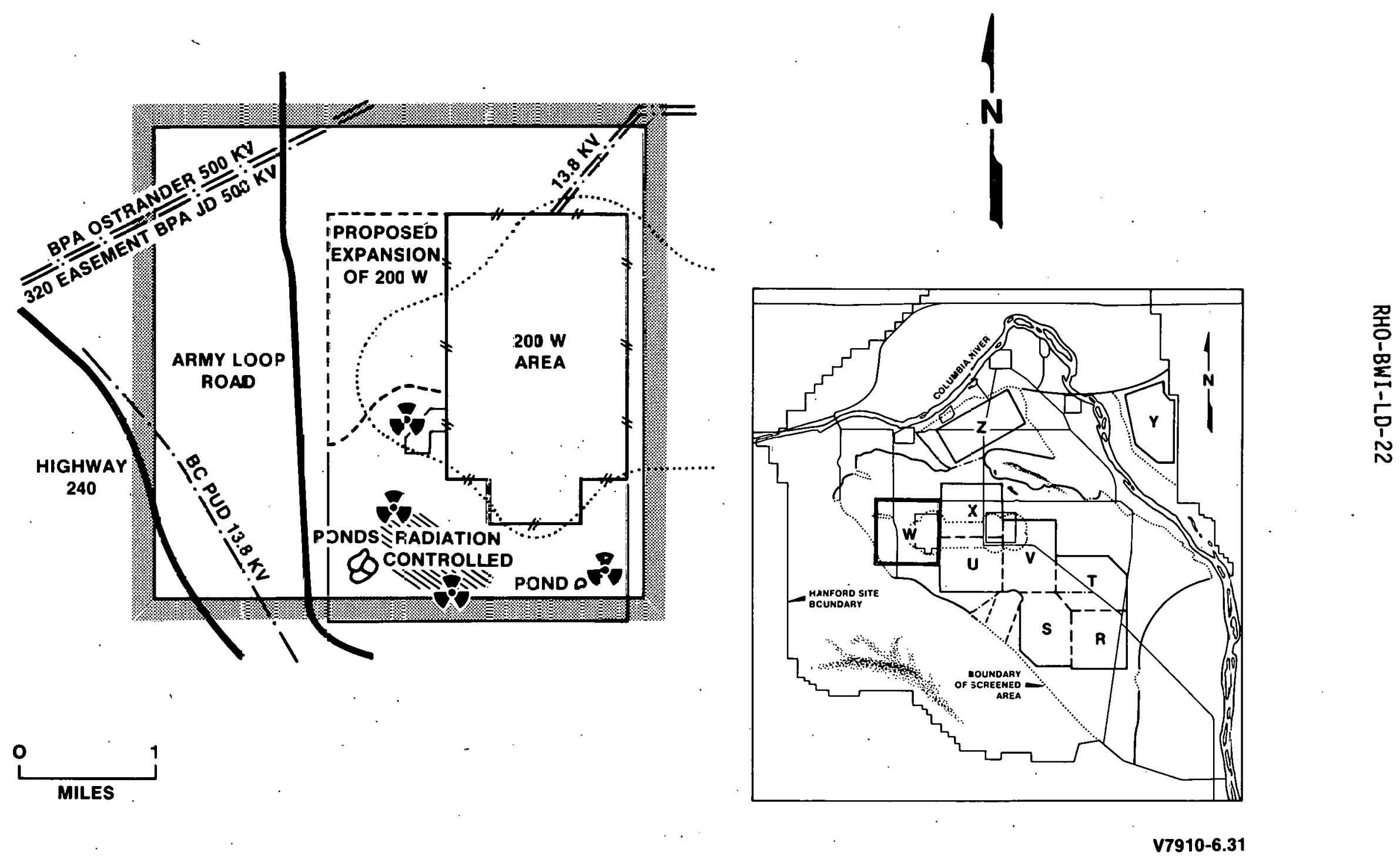


\section{CANDIDATE SITE X}
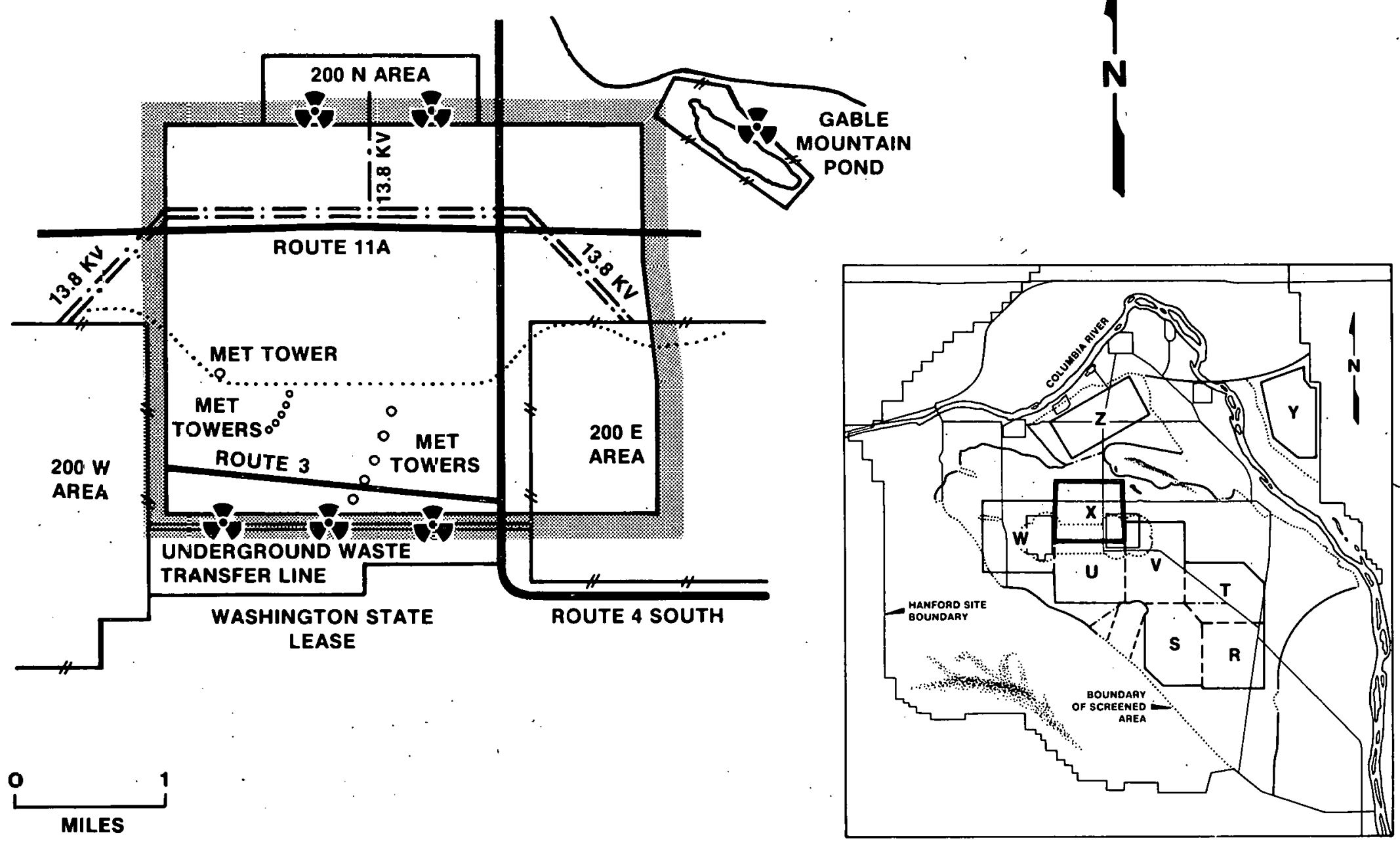
CANDIDATE SITE $Y$

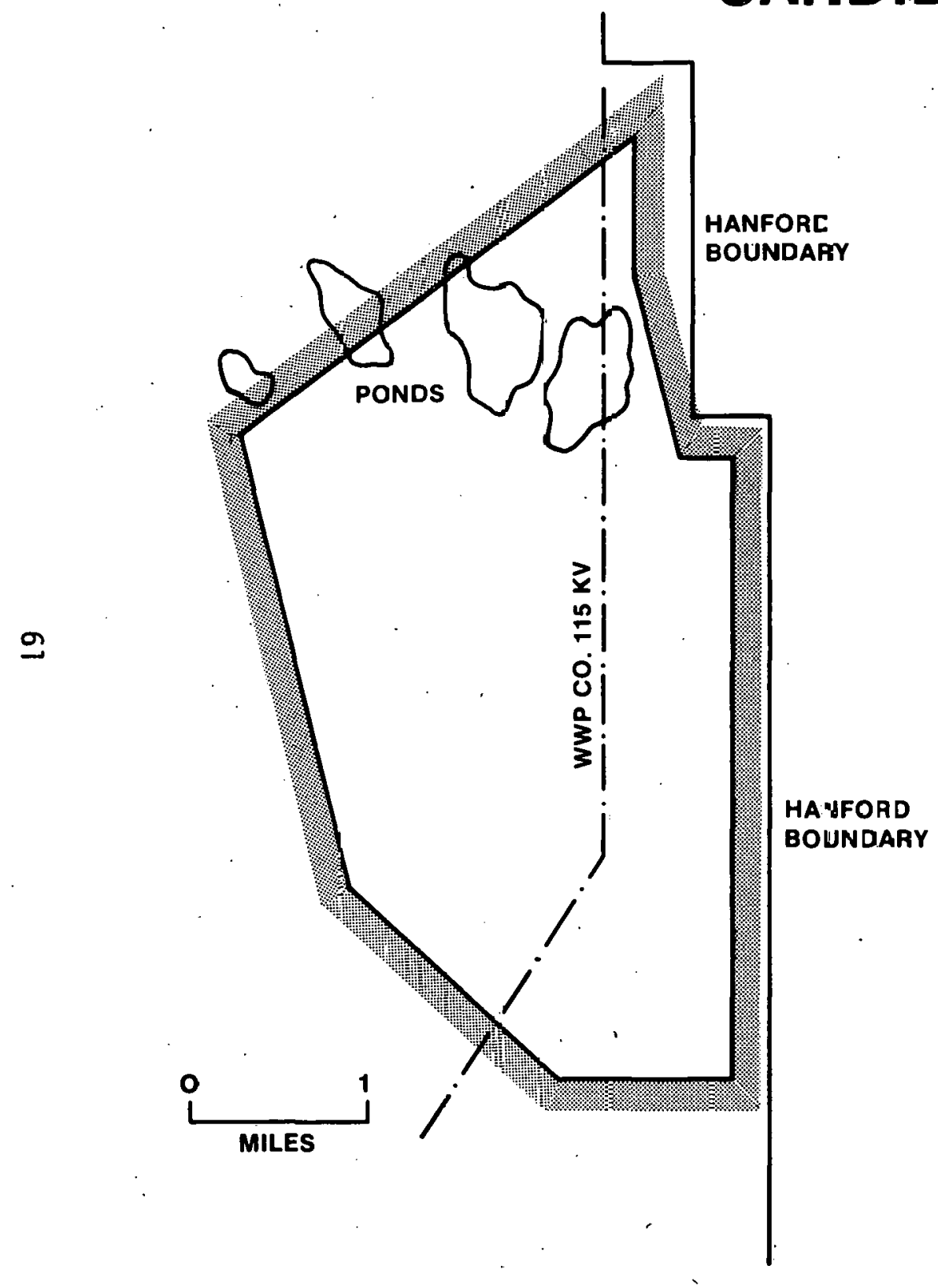

종
1
$\frac{1}{2}$
1
$\frac{1}{1}$
N 


\section{CANDIDATE SITE Z}
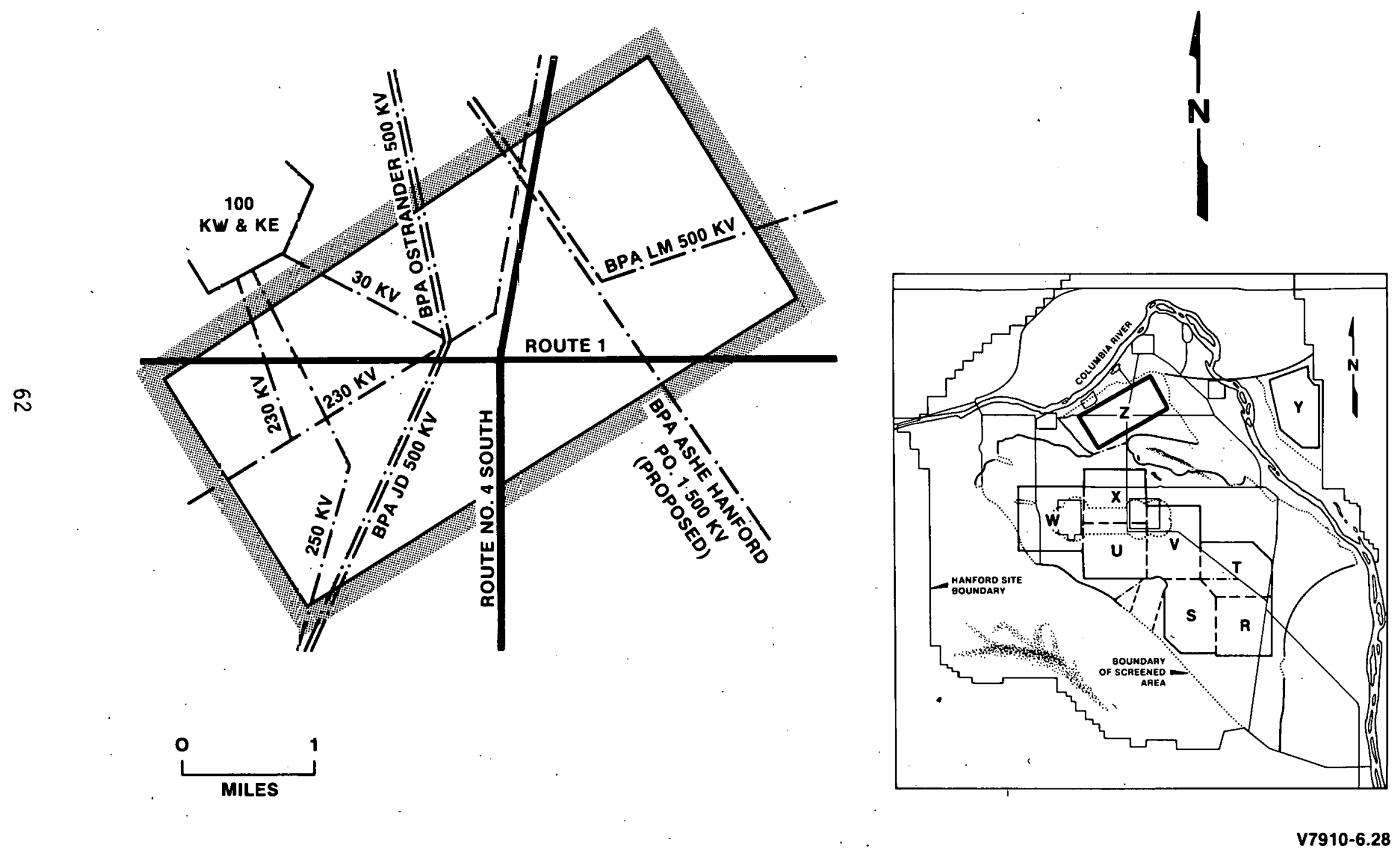


\section{AREA FOR SITE CHARACTERIZATION}

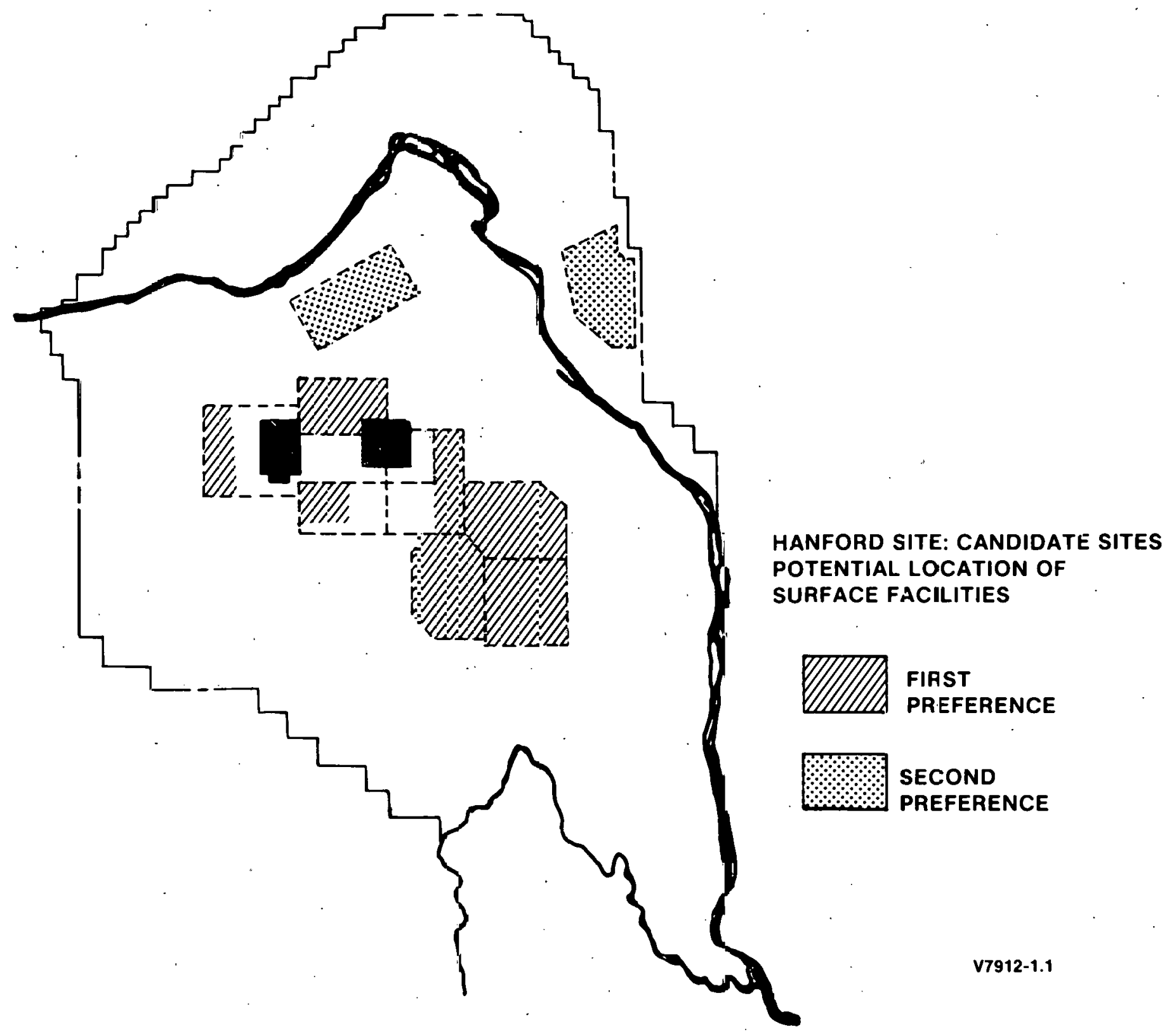




\section{A) Natural Hazards}

1) Fault Rupture

a) Horizontal and vertical distance from kncwn faults interpreted to be capable

b) Horizontal and vertical distance from kncwn faults interpreted to be not capable and zones of fracturing and jointing

2) Ceneration of New Faults

3) Ground Mo:ion c) Location with respect to lineaments and postulated faults Location with respec to future
potentially capable =ectonic structures

Location with respect to potential earthquake sources and estimated levels of ground otion a) Inciude areas > 5 miles, horizontally and vertically, from known faults interpreted to be capable

b) Include areas > 5 miles, horizontally and vertically, from known faults whose and vertically, from know have capability is unknown which have iow

a) Include areas > 1/2 mile from known faults interpreted to be not capable and from zones of fracturing and jointing

b) Include areas > 1/2 mile from known faults whose capability is unknown, but which have a high.potential for a capability evaluation

Evaluate areas on basis of proximity to linear features (lineaments) as interpreted from remote sensing and geophysical data and postulated faults

Include areas $>5$ miles from folds interpreted to be capable of forming new faults

a) Include areas that may be subject to < $40 \% \mathrm{~g}$ peak surface acceleration from known and interpreted earthquake sources

b) Include areas $>12$ miles from the felt epicenters >MM $V$ and $>6$ miles from instrumental epicenters > magnitude 4.0 which occur in concentrations or clusters as interpreted from historic earthquake epicenter plot maps

\begin{tabular}{|c|c|}
\hline $\begin{array}{l}\text { Candidate Area } \\
\text { Sub-area } \\
\text { Site Locality }\end{array}$ & $\begin{array}{l}O \text { and } I \\
S \text { and } U\end{array}$ \\
\hline $\begin{array}{l}\text { Candidate Area } \\
\text { Sub-area } \\
\text { Site Locality }\end{array}$ & \\
\hline Site Locality & $\begin{array}{l}O \text { and } I \\
S \text { and } U\end{array}$ \\
\hline
\end{tabular}

Site Locality

Site Locality

0 and 1

$S$ and $U$

Sub-area

Site Locality

0 and I

$S$ and $U$

Candidate Area

0 and I

$S$ and $U$

Sub-area

$\mathrm{S}$ and I

(1) $0=$ Operation Phase $(0$ to 60 years); I = Isolation Phase $(10,000$ years $)$

(2) Applicab:lity of guidelines to the surface $(S)$ repository facilities and/or the subsurface (U) repository facilities 
c) Evaluate areas and their locations with

Site Locality

respect to isolated earthquakes of

epicentral intensities $>$ MM $v$ and magnitude $>4.0$ based on estimated location errors and geologic and. tectonic setting

d) Evaluate areas and their locations with respect to shallow (< 35 miles depth) microearthquakes based on location error, geologic and tectonic setting.

4) Tectonic Movement

Location wití respect to potential besrock folding

5) Groundwater Contamination

Location witi respect to nazural and an-made discharge areas.
6) Flooding

\section{Height above selected floor} level

\section{Distanze frai Quaterrary}

Volcanic asifall sources and local and regional stress regime

Evaluate areas on basis of proximity to sedrock folds (anticlines, synclines, or nonoclines)

Evaluate areas on basis of distance from Jischarge areas and interpreted contaminant travel time

a) Include areas outside of primary floodplains and published maximum flood levels

b) Evaluate areas on basis of height above primary floodplains and estimated published maximum flood levels

c) Evaluate areas on basis of location with respect to areas where catastrophic flooding (i.e., Spokare Floods) has occurred in Quaternary

Evaluate areas on basis of exposure to tephra fall from Quaternary stratovolcanoes

$$
\begin{aligned}
& A=>150 \text { miles to source } \\
& B=40 \text { to } 150 \text { miles to source } \\
& C=<40 \text { miles to source. }
\end{aligned}
$$

Site Locality

Site Locality

(2) Applicability of guidelines to the surface (S) repos'tery iacilities and/or the subsurface (U) repositorj facilities 
Consideration

8) Future New Volcanic Activity

9) Ground Fai ure

b) Characteristics of foundation conditions

on

10) Erosion/ Denudation

Location with respect: to potential areas of reosion or denudation

11) Stratigraphic Characteristics

\section{Lacation with respect to} probability of new volcanic scurces

a) Location with respect to landslides and potential landslides
Guideline

Evaluate areas on basis of probability and proximity' to areas of interpreted new volcanic sources and effects

a) Include areas not on mapped landslides

Site Locality

b) Evaluate areas on basis of probability of landsliding

Site Locality

$A=$ Low probability of a landslide

$B=$ Slight probability of a landslide

$C=$ Higher probability of a landslide

Evaluate general foundation conditions

$A=$ Bedrock area ( 0 to 20 feet consolidated material)

$B=$ Shallow alluvial area (20 to 100 feet unconsolidated material

$C=$ Deep alluvial area ( $>100$ feet unconsolidated material)

a). Include areas > 1/2 mile from steepwalled canyons or slopes

b) Evaluate areas on basis of height of underground repository above base. level

$A=$ Repository elevation below base level (sea level) $\begin{aligned} B= & \text { Repository elevation above base } \\ & \text { level (sea level) }\end{aligned}$

Evaluate areas on basis of bedrock dip

$$
\begin{aligned}
& A=0 \text { to } 5 \text { degrees } \\
& B=5 \text { to } 10 \text { degrees } \\
& C=<10 \text { degrees }
\end{aligned}
$$

(1) $0=$ Operation Phase ( 0 to 60 years); I = Isolation Phase ( 10,000 years)

(2) Applicability of guidelines to the surface (S) repository facilities and or the subsurface (U) repository facilities 
Summary of Guidelines Used for Screening icontinued)

Consideration

Measure

b) Presence of suitable stratigraphic charact -1

c) Thicknes; of underlying basalt

\section{B) Man-Made Hazards}

1) Aircraft Impact

a) Distance from airoorts
Possible Use
to Obtain

Include areas where basalt flow with

desirab e internal flow structure, density,

porosity, extent, continuity, etc. are

$>100$ feet thick within the proposed

repository depth zone

Include areas where thickness of under-

lying repository host rock-type material

at the repository depth is $>500$ feet

a) Inc ude areas > 5 miles from airports shown on state airport plans, accommodating aircraft $>12,500$ lbs. gross weight or any military airport

b) For airports with $>12,500$ operations per year but less than 50,000 , include areas $>d \mathrm{miles}$ from airport

\section{$d=\sqrt{0.002 \text { (operations) }}$}

c) For airports with 50,000 to 100,000 operations per year, 10 miles from airport. For airports with $>100,000$ operations per year, include areas $>d$ miles from airport

\section{$d=\sqrt{0.001 \text { (operations) }}$}

b) Locations with respect to comercial jet rostes and military routes

c) Location with respect to restr-cted air:space

2) Hazardous Facilities

a) Location with respect to hazardous facilities, possitle missile generators and poss'ble vapo" sources
Evaluate areas with respect to proximity to high-frequency routes

Include areas away from the limits of restricted airspace defining military airspace usage

a) Inciude areas away from facilities

b) Inciude areas > $0.6 \mathrm{mile}$ from potential explosion, fire, missile hazerds occupying 18,000 acres or more
Site Locality

Site Locality

and 1

Applicability and Time Frame $(1,2$

0 and I

Candidate Area

S

Sub-area

(1) $0=$ Operation Phase ( 0 to 60 years); I = Isolation Fbase $\{10,000$ years $)$

(2) Applicability of guideliries to the surface $(S)$ repos tory facilities and/or the subsurface (U) repository facilities 
Consideration

3) Transporta:ion

b) Distance from transportation corridors

4) Induced Seismicity

이

5) Subsurface Mineral

Exploration

and Extracion

6) Netional

Defense and

Security
Location with respect to existing and potential furture mineral exploration and extraction

Proximity to facilities or areas interpreted to be possible defense or sezurity risks

c) Include areas $>0.6 \mathrm{mi}$ le from potential sources of noxious or flammable vapors

d) Evaluate areas on basis of proximity

Site Locality to hazardous facilities

Site Locality

Include area's $>0.6 \mathrm{mile}$ from U.S. highways, interstate highways, rail roads, and navigable highways

b) Evaluate areas: on basis of proximity to transportation corridors

Site Locality

Sub-area

Include areas $>5$ miles from existing reservoirs $>100$ feet deep

b) Evaluate areas on basis of proximity to future reservoirs and interpreted sources of induced seismicity

Site Locality $A=>5$ miles

$B=0$ to 5 miles

a) Include areas away from existing subsurface mineral extraction

Site Locality

0 and I

b) Evaluate areas on basis of proximity to potential future mineral exploration or extraction

Evaluate areas on basis of proximity to facilities or areas interpreted to be attractive military or terrorist targets

Site Locality

Site Locality

characteristics 


\section{Consideration}

2) Operationa Radiation Release

Distarice fram population
2) Culturally Important Areas

a! Location with respect to designated scenic areas

Indian reservations, $\quad b^{\prime}$. Location with respect to parks, monuments,

wilderness, primi-

tive areas, road

national forest

Bureau of Land

Management road-

less recreation

area, archaeological

sites

3) Protected arid

Endangered Species

Location with respec: to protected ard endangered species

4) Biologically Important Areas
Location with respect to bialogicalls important areas Location with respect to pro-
tected ecological areas
Guideline

a) Include areas $>3$ miles from populations of $>2,500$

b) Include areas $>1 \mathrm{mile}$ from any incorporated community

c) Include areas > 1 mile from any urbanized area

Include areas outside of designated protected. ecological areas of

a) $\geq 18,000$ acres

b) 5 to 18,000 acres

c) $<j, 000$ acres

Include areas greater than a calculated cistance based on height of surface repository

Include areas outside of designated culturally important areas

a) $\geq 8,000$ acres

b) 5 to 18,000 acres

c) <5,000 acres

I Iclude areas outside of known locations of protected and endangered species

Eraluate areas based on proximity to biologically important areas
Sub-area

Canididate Area Sub-area

Candidate Area Sub-area

Candidate Area Sub-area

Applicability and Time Frame

(1) $0=$ Operation Phase $(0$ to 63 years); I = Isolation Phase $(0,0,000$ years)
(2) Applicability of guidelines to the surface $(S)$ repository acilities and/or the subsurface $(U)$ repository facilities 
Summary of Guidelines Used for Screening (continued)

Consideration

Measure

Guideline

Possible Use

to Obtain

Applicability and.Time Frame

5) Existing

Significant,

Specialty, or

Incompatibile

Land Uses

6) Potential

Significant

or Incompatible

Land Uses

Location with respect to
significant, specialty,

significant, specialty,
incompatible land uses

Location with respect to

potential future significant

or incompatible land uses

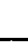

Include areas outside of mapped extent

of specialty, agriculture, irrigated

agriculture, incompatible facilities, or other land uses that are locally limited and regionally significant

Evaluate areas with respect to potential future uses. The evaluation will focus

on agriculture

Sub-area

a) Potentially irrigable lands

b) Arable soils

c) Marginal soils

d) Submarginal soils

\section{OBJECTIVE: MINIMIZE SYSTEM COSTS}

a) Terrain ruggedness

t) Usable land area

2) Site

Preparation

Mining and excavation

(Subsurfaze)

Subjective evaluation for terrain characteristics (i.e., slope approximately $>15 \%$, relief and degree of dissection)

Evaluate available land area for dominant site preparation costs, slope, local relief, degree of dissection, size of area, location and juxtaposition of relatively level areas, water supply, access, and amount of excavation and fill necessary to fitt 2,400 acres of surface facilities

Evaluate areas on basis of thickness of overburden, depth of shafts, host rock characteristics, configuration, and

length of tunneis (spoil, etc.), excavated volume, etc.
Candidate Area

Site Locality

(1) $0=$ Operation Phase ( 0 to 60 years); I = Isolation Phase $(10,000$ years)

(2) Applicability of guidelines to the surface (S) repository facilities and/or the subsurface (U) repository facilities 
DISTRIBUTION

Number of

Copies

1

1

6

2

1

1

1

3

18

AMOCO

G. Servos

ATOMICS INTERNATIONAL

H. C. Wieseneck

BATTELLE-OFFICE OF NUCLEAR WASTE ISOLATION

N. E. Carter

Library (5)

BECHTEL INCORPORATED

R. A. Langley, Jr.

CALIFORNIA ENERGY RESOURCES CONSERVATION

AND DEVELOPMENT COMMISSION

E. Varanini

LAWRENCE LIVERMORE LABORATORY

L. D. Ramspott

LOS ALAMOS SCIENTIFIC LABORATORY

K. Wolfsberg

NATIONAL ACADEMY OF SCIENCES
W. E. Berg
D. Daley
S. Stuen

NATIONAL ACADEMY OF SCIENCES - COMMITTEE ON RADIOACTIVE WASTE MANAGEMENT
M. Baram
H. L. James
S. N. Davis
R. E. Kasperson
E. L. Draper
K. B. Krauskopf
P. W. Durbin
T. R. LaPorte
J. T. Edsal1
C. Mawson
M. Eisenbud
F. L. Parker
J. A. Fay
J. C. Frye
T. Pigford
E. F. Gloyna
R. Roy
E. Wenk, Jr. 
Number of

Copies

5

1

1

1

1

i

2

1

5

1
SANDIA LABORATORIES

E. H. Beckner

R. C. Lincoln

A. E. Stephenson

L. D. Tyler

W. D. Weart

STANFORD UNIVERSITY

I. Remson

STATE OF IDAHO GOVERNOR'S OFFICE

C. Jones

STATE OF OREGON GOVERNOR'S OFFICE

K. Woods

STATE OF WASHINGTON GOVERNOR'S OFFICE

D. Jankins

SWEDISH NUCLEAR FUEL SUPPLY COMPANY (KBS)

L. B. Nillson

U. S. BUREAU OF MINES

J. W. Corwine

U. S. DEPARTMENT OF ENERGY-ALBUQUERQUE OPERATIONS OFFICE

D. T. Schueler

U. S. DEPARTMENT OF ENERGY-COLUMBUS PROGRAM OFFICE

J. 0. Neff

U. S. DEPARTMENT OF ENERGY-HEADQUARTERS
C. R. Cooley
M. W. Frei
C. H. George
C. A. Heath
D. L. Vieth

U. S. DEPARTMENT OF ENERGY-NEVADA OPERATIONS OFFICE

R. M. Nelson, Jr. 
Number of

Copies

U. S. DEPARTMENT OF ENERGY-PUBLIC READING ROOMS

Richland, Washington

Seatt le, Washington

6

U. S. DEPARTMENT OF ENERGY-RICHLAND OPERATIONS OFFICE

T. A. Bauman

R. B. Goranson

A. G. Lassila

B. L. Nicoll

D. J. Squires

F. R. Standerfer

6

U. S. GEOLOGICAL SURVEY

C. Collier

G. D. DeBuchananne

R. Schneider

P. R. Steven

D. A. Swanson

W. S. Twenhofel

5

II. S. NIICI EAR RFGIII.ATORY ROMMISSSION

R. Boyle

J. 0. Bunting, Jr.

J. C.'Malaro

J. B. Martin

E. P. Regnier

1

WASHINGTON PUBLIC POWER SUPPLY SYSTEM, INC.

D. D. Tilison

1

WASHHINGTON STATE DEPARTMENT OF ECOLOGY

P. M. Grimstad

WASHINGTON STATE DEPARTMENT OF NATURAL RESOURCES

V. K. Livingston

1

A. C. WATERS

2

R. C. Mairson 


\section{Number of}

Copies

41

ROCKWELL HANFORD OPERATIONS

R. J. Bielefeld

D. J. Cockeram

R. A. Deju

R. J. Gimera

R. N. Gurley

K. H. Henry

G. S. Hunt

A. D. Krug

W. J. Kurzeka

D. R. St. Laurent

Document Control (4)

Records Retention Center (2)

Basalt Waste Isolation Project Library (25) 